\title{
Mesenchymal Stem Cells Manage Endogenous Tissue Regeneration
}

\author{
Anna Meiliana ${ }^{1,2,}$, Nurrani Mustika Dewi ${ }^{1,2}$, Andi Wijaya ${ }^{1,2,3}$ \\ ${ }^{1}$ Postgraduate Program in Clinical Pharmacy, Faculty of Pharmacy, Padjadjaran University, Jl. Eijkman No.38, Bandung, Indonesia \\ ${ }^{2}$ Prodia Clinical Laboratory, Jl. Cisangkuy No.2, Bandung, Indonesia \\ ${ }^{3}$ Postgraduate Program in Clinical Biochemistry, Faculty of Medicine, Hasanuddin University, J1. Perintis Kemerdekaan Km.10, Makassar, Indonesia \\ *Corresponding author. E-mail: anna.meiliana@prodia.co.id
}

Received date: May 15, 2016; Revised date: Jul 11, 2016; Accepted date: Jul 28, 2016

\section{Abstract}

B ACKGROUND: Current findings set a new understanding that every adult tissue has its own intrinsic progenitor or stem cell, give a potency for their innate turnover dynamics. This broke the old assumption that adult tissues cannot regenerate themselves. Localized tissue regeneration was regulatory oversight by a separate class of local cells originating as perivascular cells, suggested a profound influence on using specific cells for cell therapies as a health care delivery tool set.

CONTENT: The mesenchymal stem cells (MSCs) could be mobilized from the marrow or other depots or can be culture-expanded MSCs which are delivered to the damage site either by direct or systemic injection. MSCs act paracrine and autocrine by inducing a variety of cytokines and growth factors which suppress local immune system, inhibit fibrosis (scar formation) and apoptosis, enhance

\section{Introduction}

Mesenchymal stem cells (MSCs), which also referred to as mesenchymal or multipotent stromal cells was first discovered in the bone marrow in early 1970s.(1) After more than 30 years of research and an ever increasing number of published reports, MSCs have been subsequently found in many tissues, such as umbilical cord blood, adipose, brain, liver, lungs (2-8) and are seen as promising cells for the treatment of a large variety of disorders, including cardiovascular, neurodegenerative and autoimmune diseases $(9,10)$. Several pre-clinical studies have been angiogenesis, and stimulate mitosis and differentiation of tissue, intrinsic reparative or stem cells. These referred a trophic effects, different from the direct differentiation of MSCs into repair tissue. Thus, MSC suggested as a multidrug delivery vehicles in response of injury. In this regard, the trophic effects of MSCs may have profound clinical use.

SUMMARY: Managing the body's natural repair and regeneration capacities is the new frontier for modern medicine and the basis for the science of cell therapies. Study of MSCs become one avenue that being pursued to explore the endogenous tissue regeneration management, so that people have a great expectation to solve many severe diseases.

KEYWORDS: mesenchymal stromal/stem cell, paracrine or autocrine activities, trophic mediator, inflammation, wound healing

Indones Biomed J. 2016; 8(2): 71-90 described the therapeutic potential of MSCs using various animal models of disease, with the latest investigations mostly focused intensely on mechanisms of effect. Three major functions of MSCs have been associated with their therapeutic effects, those are tissue replacement via multipotent differentiation $(11,12)$, immunomodulatory and anti-inflammatory effects $(13,14)$ and the secretion of molecules that instigate or assist in tissue repair (i.e., paracrine activity) (15-17).

Whether called mesenchymal stem cells, mesenchymal stromal cells, multipotent stromal cells, skeletal stem cells, or other names, this class of stem/progenitor cells has been continuously studied for more than two decades. More than 
30,000 publications about more than 300 clinical trials on over 10,000 subjects received either MSCs or MSC-like cells, started from two decades ago, and studies about the science of MSCs and their therapeutic potential were still going. MSCs safety records remains strong.(18)

MSCs are defined by their capacity to differentiate to osteoblasts, chondroblasts and adipocytes, by plastic adherence and by a peculiar expression pattern of certain surface proteins.(1,19) Firmly attracted to wounds, MSCs are mobilized by injuries which they enter to modulate inflammatory responses and stimulate tissue regeneration.(20) MSCs are a heterogeneous population and also able to emerge from pericytes or endothelial cells (21), which may help to accelerate local MSC recruitment. MSCs were originally known to have role in tissue repair by trans-differentiating into cells, such as epithelial cells or neurons, which are required to restore the injured tissue.(22-25) However, later it became evident that their paracrine activities are more important for wound healing than their differentiation potential.(21,26-28)

It is important to understand that all adult stem cell systems exist to guarantee that when cells within tissues expire naturally, these cells can be expeditiously replaced to provide physiological balance in the organism. Every cell in the body has a lifespan ranging from 20 minutes to many years depending on the cell. Some circulating blood cells expire in 20 minutes after forming, while neurons exist for many years. The expiration allows the tissue to rejuvenate itself and provides it with a mechanism to slowly change its properties as a function of age and/or use. Hence, not only the stem cells are source of replacement parts for expired units, but they also serve as reserve cells for damaged or compromised adult tissues requiring more extensive repair, regeneration or expansion. $(7,14,28)$ Caplan has suggested that the acronym MSCs be retained for this class of cells, but that it should stand for medicinal signaling cells.(29) Clearly, the major function of MSCs in vivo is not as multipotent progenitor stem cells, but as cells that help to manage repair and/or regeneration at sites of injury.(30-33)

The management of these composite trophic activities is an inherent capacity of MSCs independent of the tissue of origin. Each tissue houses MSCs/pericytes have different chemistries because of the local environments in which they are housed. The small amount of data now available suggests they all have the same sensory and response elements (immunomodulatory and trophic) even when expanded in culture under very different culture conditions.(34-37) If we analog these to the computer's working components, MSCs are used as the central connection in the broad theme, not as multipotent progenitors but rather as an important control element in the natural local regeneration process, and cells are meant to draw several important scientific principles.(38)

\section{MSC as Medicinal Signaling Cell}

The publication by Crisan, et al., is a landmark paper which presents a wide body of work that defines, refines, confirms, establishes and validates both the in situ and in vitro links between adult human MSCs and perivascular cells, summarily referred to here as pericytes.(39) Two important recent pieces of information strongly argue that Caplan should rename the MSCs. First, MSCs can be isolated from almost every tissue in human body, since all these tissues are vascularized and every vessel has MSC in abluminal locations. These perivascular cells can be summarily called pericytes. $(40,41)$ This led us to suggest that "all MSCs are pericytes".(39) But the opposite, that all pericytes are MSCs, is not correct. Since some pericytes exhibit highly specialized characteristics and do not exhibit MSCs multipotency properties.(29) The second issue is that MSCs are being used therapeutically because they home to sites of inflammation or tissue injury (42) and they secrete massive levels of bioactive agents that are both immunomodulatory (13) and trophic (43).

The documentation that MSCs are derived from perivascular cells, pericytes $(39,41)$, now explains how MSCs can be isolated from almost every tissue in the body $(44,45)$. Moreover, the fact that MSCs have the ability to secrete immunomodulatory and trophic mediators strongly argues that their natural and normal in vivo function is as "medicinal signaling cells" for sites of injury or inflammation in all of the tissues in which they are housed.(29,31) Today on the website clinicaltrials.gov a search using "mesenchymal stem cells" in the website's search engine shows that over than 500 clinical trials are listed covering a surprisingly big array of clinical conditions, with most of these studies using either immunomodulatory or regenerative (trophic) aspects, or both, as the central components of MSCs' therapeutic intention.

The realization that MSCs are acquired from pericytes changes the context of considering how MSCs arise and function in vivo during the body's response to both localized injury and the demand for regeneration/repair. Pericyte released in its simplest origin from its association with the basal lamina of the blood vessel where the injury or inflammation occurred, and sensing its surrounding milieu then responding by growing into MSC. It will 
soon be activated and dynamically changes while keyed to the detailed chemistry of its niche. MSCs that have been activated put out a concentrated localized curtain of bioactive molecules that serves to inhibit the interrogating cells of the body's overaggressive immune system. $(46,47)$ This acts as the first-line defense against the autoimmune reactions which established due to injured tissue in the immediate region. Together with this curtain, MSC coordinately secretes molecules set up for regenerative (not repair) microenvironment.

Thus, MSC thought to play a critical role by secreting some bioactive factors for mediating immune/inflammatory suppression and paracrine activity. Some proteomic studies have recently carried on for a deeper understanding about MSC potencies in clinical setting. Majority of these studies have utilized either shotgun broad range scanning or targeted proteomic approaches (i.e., candidate-based) to uncover soluble or extracellular vesicle (EV) bound factors present in MSC conditioned media (CM). A subset of investigations have conducted cell-free-based animal studies with MSC$\mathrm{CM}$ or CM-derived EVs (e.g., exosomes and microvesicles) to further show the therapeutic relevance of their findings.(15)

Some studies in rodents clearly shown a good results of MSC in promoting regeneration of damaged tissues without any significance engraftment $(48,49)$, and these support the idea of MSC's paracrine activity in mediating tissue repair by secretes bioactive molecules such as interleukins (IL) and tumor growth factors (TGF) that promote regenerative microenvirontment in the injury vicinity. $(15,16,50,51)$ To date, therapeutic response of $\mathrm{CM}$ has been tested in disease models for lung injury (15), chronic kidney disease (50) and liver injury (16,51), among others, and demonstrate that MSC-CM alone is sufficient to mediate lasting therapeutic effects.

It is evident from the current body of research that immune/inflammatory modulation and paracrine factors contained within the MSC secretome function in a cooperative manner to generate a tissue microenvironment that is more permissive of repair/regeneration. In the last decade, investigators have made progress towards characterizing CM and EVs derived from MSC. These studies have identified plenty candidate modulators of paracrine effects and cell-mediated/inflammatory suppression.(17) Taken together, the current body of research seems to argue that multipotent differentiation have minimal contribution in beneficial effects attributed to MSC while immune/ inflammatory suppression and paracrine activity have a more predominant role.

\section{MSC as Thropic Mediator}

MSCs can differentiate into bone, cartilage, muscle, marrow stroma, tendon-ligament, fat and other connective tissues. So, what do MSCs do naturally and where is the MSC niche? New insight and clinical experience proposes that MSCs are naturally found as perivascular cells, summarily referred to as pericytes, which are released at the sites of injury, where they secrete large quantities of bioactive factors that are both immunomodulatory and trophic such as growth factors, and cytokines that can suppress T cells activity.(52)

Virtually, MSC presents in all tissue and interact with tissue cells and immune cells under the condition of inflammation. Due to their multipotent differentiation capacity, they can differentiate into osteoblasts, adipocytes, chondrocytes, etc., while with their immunomodulatory capacity they sense and control inflammation and modify the cytokines proliferation and expression in lymphocytes and myeloid-derived immune cells.(53)

While it was originally predictable that MSCs could be used for replacement of dysfunctional cells through their capacity to differentiate into tissue cells (54), the current paradigm is that MSCs support resident progenitor cells via paracrine mechanisms $(55,56)$. This idea may be even need refinement, as recent studies suggest that MSCs may not have a long lifespan after administration. $(57,58)$ The reason why this may be the case is not clear. After administered, MSCs disappear rapidly, so this raise questions of how its work? Some suggestions think than a small fraction could escape from death then migrate into the injury or inflammation site for doing their work, or, they were indeed could pass on their beneficial effects in mediating tissue repair or immunomodulation very rapidly. Even the clean-up process of MSCs itself may be a trigger for the therapeutic effects of MSCs.(59)

In all cases, it appears that MSCs do not differentiate into cardiac myocytes, meniscal cells or neurons. Instead, the MSCs exert their influence by the secretion of huge amounts of growth factors (stem cell factor (SCF), granulocyte-colony stimulating factor (G-CSF) and stromal cell-derived factor 1 (SDF-1)) and cytokines (IL-2, IL10) to affect a therapeutic outcome. We call these effects 'trophic' activity (14), named after this term that was related to neural effects (59). All of these models to have a common trophic mode of action of the MSCs: the MSCs secrete bioactive molecules that: (a) inhibit apoptosis and limit the field of damage or injury; (b) inhibit fibrosis or scarring at sites of injury; (c) stimulate angiogenesis and 
bring in a new blood supply; and (d) stimulate the mitosis of tissue-specific and tissue-intrinsic progenitors, such as cardiac or neural stem cells.(14) The immunomodulation inhibits lymphocyte surveillance of the injured tissue, thus preventing autoimmunity, and allows allogeneic MSCs to be used in a variety of clinical situations. Thus, a new, enlightened era of experimentation and clinical trials has been initiated with xenogenic and allogeneic MSCs.

The bioactive molecules secreted from MSCs work either directly by promote intracellular signaling, indirectly by induce vicinity cells to secrete the functionally active agents, or even both. The indirect effect of MSCs refers as trophic effect, consistent as neurobiology term to indicate the bioactive molecules released from nerve terminals that are not neurotransmitters. $(60,61)$ As seen in Figure 1, MSCs can have two distinct functions. MSCs is able to provide replacement units for expired cells in mesenchymal tissues, and MSCs can have trophic effects on cells in their vicinity without creating newly differentiated mesenchymal phenotypes and, thus, also influence the regeneration of cells or tissues by purely a bioactive factor effect (Figure 2).(12)

Studies documented the effects of transplanted MSCs expressing the pro-survival gene Akt1, and the scientists recognized that the molecules released by trans-planted MSCs are important.(62) The trophic effects of MSCs have been documented by Tang, et al., who showed that MSCs implanted into ischemic myocardium simulated an increased production of vascular endothelial growth factor (VEGF), increased vascular density and blood flow, and decreased apoptosis, all of which were likely influenced by the secretion of bioactive molecules.(63)

However, the use of MSCs as site-regulated multidrug dispensers, especially allogeneic MSCs, opens avenues of therapy unimagined around 5-10 years ago. For example, uses of MSCs in asthma (64), radiation exposure (65), neurological disorders (65), etc., are now being explored. How to deliver a precise dose of MSC to be effective in

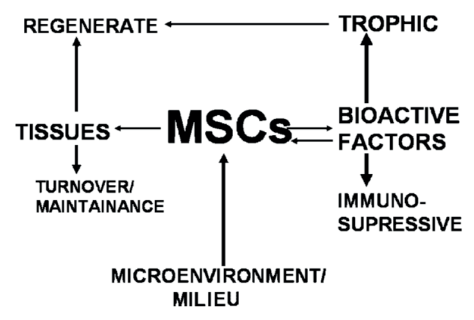

Figure 1. The dual roles of MSCs. MSCs play a central role in aspects of tissue regeneration and repair, maintenance and turnover and the control of hematopoiesis in the bone marrow.(14) (Adapted with permission from Wiley-Liss). their site of action and where is actually their main site, still become a challenge, since not all blood vessels or pericytes are the same. Similarly that MSCs from different source must be different in their responses and activities. $(67,68)$ Are the MSCs from marrow better than the MSCs from fat, muscle or liver for a specific site relative to trophic activity or immunomodulation? Only time and a big amount of careful, quantitative data will help us answer these questions.

\section{MSC as Injury Drug-Store}

MSCs are the focal point of intensive efforts worldwide directed not only at elucidating their nature and unique properties, but also at developing cell-based therapies for a diverse range of diseases. More than three decade have passed since the original formulation of the concept, revolutionary at the time, that multiple connective tissues could emanate from a common progenitor or stem cell confined in the postnatal bone marrow. Despite the plentiful important advances made since that time, substantial ambiguities until plague the field regarding the nature, identity, function, mode of isolation and experimental handling of MSCs.(69)

The idea that MSCs can exert functions other than those characteristics of a stem or progenitor cell, which is tissue regeneration, is conceptually intriguing and assuredly supported by direct evidence. One defining feature of bone marrow-derived MSCs is to establish, organize and transfer the hematopoietic microenvironment or niche in vivo. $(1,40,70)$ In in vivo systems which can recapitulate the ontogeny of bone and marrow, this function is intertwined with the organization of nascent blood vessels into functional networks, which seems to be directed by MSCs through direct interaction with endothelial cells.(40) In other experimental systems that were not designed or suited to allow for the skeletogenic potential of MSCs to unfold, their ability to organize vascular networks can be portrayed even in isolation, meaning in the absence of bone or bone marrow.(71-73) Thus, at least with respect to hematopoietic cells (including hematopoietic stem cells) and endothelial cells, MSCs exert a function that is not immediately traceable to a general stem-cell property.

It is now clear that isolated pericytes exhibit a panel of cell surface markers that are identical to those expressed by isolated MSCs.(74) Furthermore, a novel cell surfacespecific marker of adipose-derived stem cells, white adipose tissue (WAT)7, which corresponds to a cleavage product of decorin, is also expressed in vivo by perivascular cells that 
exhibit typical pericyte markers such as $\beta$-type plateletderived growth factor receptor (PDGFR- $\beta$ ) and $\alpha$-smooth muscle actin ( $\alpha$ SMA).(75) These and other observations make it possible to speculate in a commentary in this journal that all MSCs are pericytes.(39) By knowing that all MSCs are indeed pericytes, the role of MSCs physiologically and therapeutically possibly can be visualized. In particular, if pericytes are the source of MSCs, what will be their local functions in the tissue microenvironment beyond their mesenchymal differentiation capabilities?

Based on the examples described above, the model that MSCs are clinically active at different tissue sites, that MSCs are pericytes and can be isolated from any vascularized tissue, and that MSCs secrete huge quantities of a different type of bioactive molecules as part of their local trophic and immunomodulatory activities. Caplan propose that this specific MSC tissue "regulatory" phenotype arises as a consequence of broken or inflamed blood vessels at sites of tissue damage.(30) This model does not exclude the possibility that pericytes naturally have an on/off cycle in the non-injured situation.

In keeping with this understanding, in cases of vessel damage, the injury will activate the pericytes release and then grow into MSCs, thereafter secreting a spectrum of bioactive molecules (i.e., drugs) which inhibit any immune

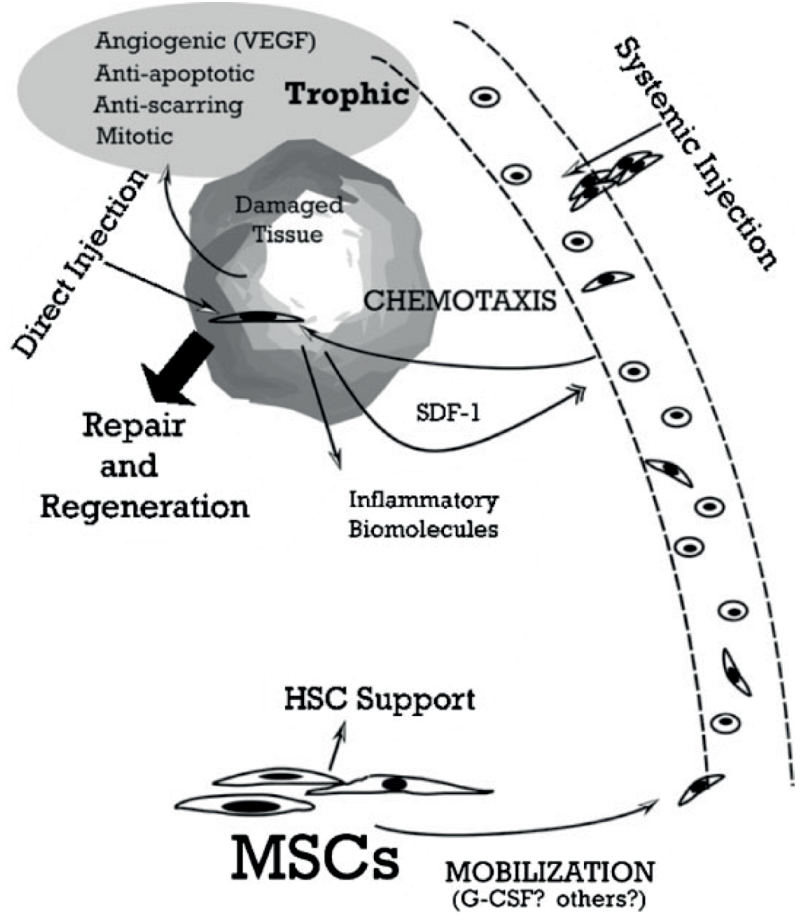

Figure 2. Trophic mechanism of tissue repair. MSCs have the capacity to trophically mediate hematopoiesis as a natural part of homeostasis.(14) HSC: Hematopoetic stem cell, (Adapted with permission from Wiley-Liss). cells to the tissue damage and also prevent autoimmune activities from developing. These bioactive molecules also establish a regenerative microenvironment to support the regeneration and refabrication of the injured tissue. In this context, the MSCs have role as site-regulated, multidrug dispensaries, or "drug-stores," to promote and support the natural regeneration of focal injuries. If these injuries are large or occur in older individuals, the natural supply of MSCs must be supplemented by local or systemic delivery.(30)

MSCs are released from their perivascular location, then become activated, and establish a regenerative microenvironment by secreting bioactive molecules and regulating the local immune response. These trophic and immunomodulatory activities offer that MSCs may serve as site-regulated "drug-stores" in vivo.(30)

\section{MSCs Manage Inflammation}

We and other vertebrates are equipped to live in a sea of microorganisms. The reason we survive is because we have formidable inflammatory and immune response systems which protect us against external confrontations with microorganisms and internal confrontations with the bacteria in our intestinal flora that outnumber the cells in our bodies. $(76,77)$ Fortunately, we have multiple systems in resolving and modulating inflammation. The systems include small molecules such as prostaglandins, lipoxins, protectins and resolvins.(78) They also include cellular phenotypes such as alternatively activated M2 macrophages (79) and regulatory $\mathrm{T}$ cells $(80,81)$. Recent reports indicate that additional important guardian cells for modulating inflammation are MSCs. The interest in the guardian role of MSCs is in part related to their presence as adventitial reticular cells that participate in normal wound repair and in regulation of hematopoietic cells in bone marrow. $(82,83)$ MSCs become very interesting because they were readily obtained from the patients, have lots of potential benefits, easily expanded by culture, and generally not tumorigenic.

The first line of defense presents by the innate immune system against invading pathogens is in form of mechanical barriers, particularly the skin and mucous membranes. In addition to their protecting and cleansing functions, these barriers regulate local and systemic immune responses by inducing inflammation or tolerance.(84) MSCs reside in local epithelial niches in close proximity to capillary walls. $(85,86)$ They might provide a life-long regenerative reservoir of new cells such as myofibroblasts (87), as well as 
trophic factors such as epidermal growth factor (EGF) and keratinocyte growth factor (KGF; also known as fibroblast growth factor (FGF)7) (88). During epithelial injury in a colitis model, the tissue-resident MSCs which sensed microbial molecules were repositioned near to epithelial progenitor cells and promoted epithelial proliferation by secreting prostaglandin E2 (PGE2) (89), which potentiates wingless/integrated (Wnt) signaling (90).

A broad panel of molecular pathways is involved in MSC-mediated immune regulation, including interferon (IFN)- $\gamma \quad(91,92), \quad$ IL-1 $\beta \quad$ (93), tumor necrosis factor (TNF)- $\beta 1$ (94-96), indoleamine-2,3-dioxygenase (IDO) $(91,92,97)$, IL-6 $(98,99)$, IL-10 (100,101), PGE2 (13), hepatocyte growth factor (HGF) (94), TNF- $\alpha$ (102-104), nitric oxide (NO) (105), heme oxygenase (HO)-1 (106), human leukocyte antigen (HLA)-G5 $(107,108)$ and many other factors, some of which are still unidentified. Apparently, there is not a unique and hierarchically prevalent mechanism responsible for MSC immune regulation. Nonetheless, redundant panel of multiple pathways, some of them reciprocally activating, eventually leads to the anergy of immune effector cells regardless their antigen-mediated activation (13,91-122) and suggests that this property must be preserved for normal tissue homeostasis and interaction with immune effector cells infiltrating the tissues when inflammation happens.

The role of MSCs as guardians of inflammation became more apparent as the events initiating inflammation have been defined in greater detail.(123-126) The events include both passive and active release from injured cells or macrophages of intracellular cytokines such as IL- $1 \alpha$ that stimulate parenchymal cells to produce chemokines which recruit neutrophils; and classical activation of resident macrophages by damage-associated molecular patterns (DAMPs) or pathogen-associated molecular patterns (PAMPs) that interact with pattern recognition receptors to produce high levels of proinflammatory cytokines as well as reactive nitrogen and reactive oxygen species (ROS) which induce the acute phase response of inflammation.(127)

The first reports describing the immunomodulatory activity of MSC were focused on their capacity to inhibit proliferation and function of T cells.(94) Subsequently, it became evident that suppression of T-cell activities was settled not only by a direct effect, but also through the inhibition of the differentiation and function of cells involved in the regulation of adaptive immune responses.(128) Hence, MSC were shown to block the generation of functional antigen-presenting cells, including myeloid dendritic cells (DC) $(101,129,130)$ and macrophages $(102,131)$. This results in cells generation but unable to efficiently stimulate type I immune responses. In some evidences, such MSC-conditioned cells showed phenotypic and functional features of regulatory cells, capable of further supress even ongoing inflammatory/ immune responses. In the case of macrophages, MSCs can induce polarization towards M2 cells.(132) M2 cells represent the so called 'alternatively activated' macrophages, which not only have regulatory activity but also participate in wound healing.(133)

Substantial advancement has been made recently in the understanding of the interactions between MSCs and immune cells. As a result of such studies, now MSCs are considered to intuitively respond to their immediate environment and to adapt their response accordingly through the release of soluble factors such as PGE2, kyneurenine, IL-10, TNF-stimulated gene 6 protein (TSG-6), NO, and transforming growth factor (TGF-b)-1 (134-139) and/ or through cell contact signaling such as Notch, and CD95/Fas (140-142). This multifaceted responsiveness is in keeping with an arising understanding of the role of primary MSCs in regulating, together with macrophages and other cell types, the bone marrow stem hematopoietic cell niche. $(143,144)$

MSCs are not constitutively immunosuppressive, they require a 'licensing' step provided by molecules of acute phase inflammation, like IFN- $\gamma$ and TNF- $\alpha$, or tolllike receptor (TLR) ligands, where TLR and their ligands can reduce MSCs motility and promote their proliferation and differentiation. $(145,146)$ Latest findings have showed that MSCs are immunosuppressive only when it is exposed to sufficiently high levels of pro-inflammatory cytokines (Figure 3).(147) In the presence of low levels of TNF- $\alpha$ and IFN- $\gamma$, MSCs may adopt a pro-inflammatory phenotype (MSC1) and enhance $\mathrm{T}$ cell responses, by secreting chemokines that recruit lymphocytes to the sites of inflammation (e.g., macrophage inflammatory protein 1 alpha (MIP-1 $\alpha$ ), macrophage inflammatory protein- $1 \beta$ (MIP-1 $\beta$ ), regulated on activation, normal $\mathrm{T}$ cell expressed and secreted (RANTES), C-X-C motif chemokine (CXCL)9, and CXCL10).(148) Under these conditions, inducible nitric oxide synthase (NOS) activity (for murine cells) and IDO activity (for human cells) are insufficient to suppress T lymphocyte proliferation (Figure 4).(147,149) The switch toward MSC1 phenotype or anti-inflammatory (MSC2) phenotype may also depend on MSC stimulation through TLRs expressed on their surface.(148) Polarization to MSC1 phenotype, important for early injury responses, can be influenced by lipopolysaccharide (LPS)-dependent 
activation of TLR4 (Figure 4), while double stranded RNA (dsRNA)-dependent activation of TLR3 may induce the polarization into MSC2 (Figure 3).(70) The balance between these opposing pathways may play role in promoting host defense on one hand and at the same time create a loop that prevents excessive tissue damage and promotes repair.(150)

Critically ill patients often suffer from multiple organ failures such as lung, kidney, liver, or brain. Genomic, proteomic, and metabolomic approaches highlight common injury mechanisms leading to acute organ failure. This underlines the urgency to focus on therapeutic strategies that affect multiple injury pathways. The use of adult stem cells such as MSCs may represent a promising new therapeutic approach as increasing evidence proves that MSC can exert protective effects following injury through the release of promitotic, antiapoptotic, antiinflammatory, and immunomodulatory soluble factors. Furthermore, they can mitigate metabolomic and oxidative stress imbalance.(151)

Both infection or non-infection causes can trigger organ damage through multiple signaling pathways such as inflammation, metabolomic disorders, oxidative stress, and apoptosis, performed during MSC therapeutic effects and lead to acute injury. MSC can exert pleiotropic therapeutic effects through the secretion of a wide array of soluble factors, which lead to: (1) antimicrobial activity, secretion of cathelicidin-related antimicrobial peptides and lipocalin, and monocytes and macrophages that increased phagocytosis; (2) anti-inflammatory activities, where M1 macrophages will be switches into M2 phenotype, inhibition of T-lymphocyte and DC activation and increase in $\mathrm{T}$ regulatory cells; (3) reducing oxidative stress by increase in ATP cellular levels and decrease in ROS accumulation; (4) switch from a proapoptotic to a pro-mitotic phenotype.(151)

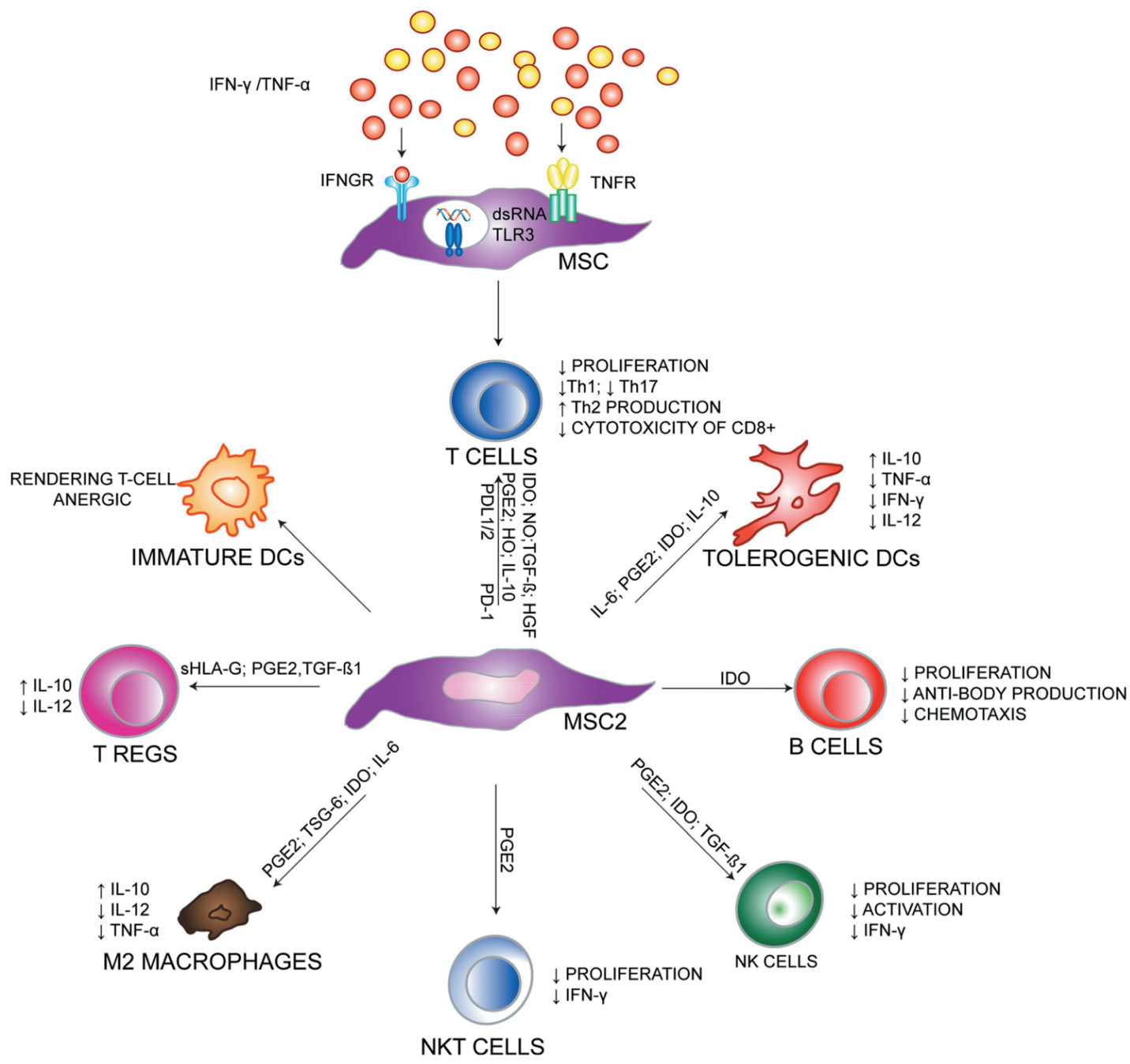

Figure 3. MSC-mediated immunosuppression. In the presence of high levels of IFN- $\gamma$ and TNF- $\alpha$ or by activation of TLR 3 by dsRNA, MSCs adopt an MSC2 phenotype. MSCs regulate proliferation, activation and effector function of a variety of immune cells, through cellto-cell contact or through producing of soluble factors including IDO, PGE2, NO, TGF- $\beta$, HGF, HO-1, IL-6, IL-10,TSG-6 and sHLA-G. (145) INFGR: interferon-gamma receptor; TNFR: TNF receptor. (Adapted with permission from Springer). 
The beneficial effects of cell-based therapy with MSCs are apparent in multiple preclinical injury models involving all the organs in Multiple Organ Dysfunction Syndrome (MODS). Attracted by signals from the injured and inflamed tissues, MSCs appear to migrate to the site of damage and secrete an array of soluble factors and/ or exosomes/microvesicles that suppress the injury. The preclinical evidence which provided the underlying rationale for several phase I/II clinical trials in Acute Respiratory Distress Syndrome (ARDS), Acute Kidney Injury (AKI), and stroke. Based on dependable preliminary results, further phase II and III trials are underway, the results of which are pending. However, no clinical studies are underway for Acute Liver Failure (ALF), Traumatic Brain Injury (TBI), sepsis, and MODS.(151)

\section{MSCs Manage Macrophage Polarization}

Macrophages are essential component in the orchestration and expression of innate immunity and adaptive immune responses. These cells play an important role in inflammation and host defense. Additionally, cells of the monocyte macrophage lineage fulfill homeostatic functions beyond defense.(152) These functions include tissue repair, wound healing, and regulation of metabolic activity.(153) Macrophages function was custom-fit to their residential tissue, as results of tissue-derived factors driven and the physiological environment.(152) Macrophages can acquire distinct functional phenotypes depend on the niche. The concept of macrophage polarization was described for the first time in 1992 with the discovery that IL-4 potently enhances murine macrophage mannose receptor (CD206) activity.(154) Since then, two opposite and competing phenotypes, often referred to as classically activated macrophages (M1 macrophages) and alternatively activated macrophages (M2 macrophages), have been defined and identified in several physiological settings.(155) Even though the classification of macrophages as M1/M2 just came after the classification of lymphocytes into Th1 and Th2, the Th1 and Th2-like responses are results of polarization of macrophages to M1 and M2 states, respectively. Moreover, M1/M2 polarization is not dependent on $\mathrm{T}$ cells, as has been demonstrated in Rag-1 knockout and other immune deficient mice.(156)

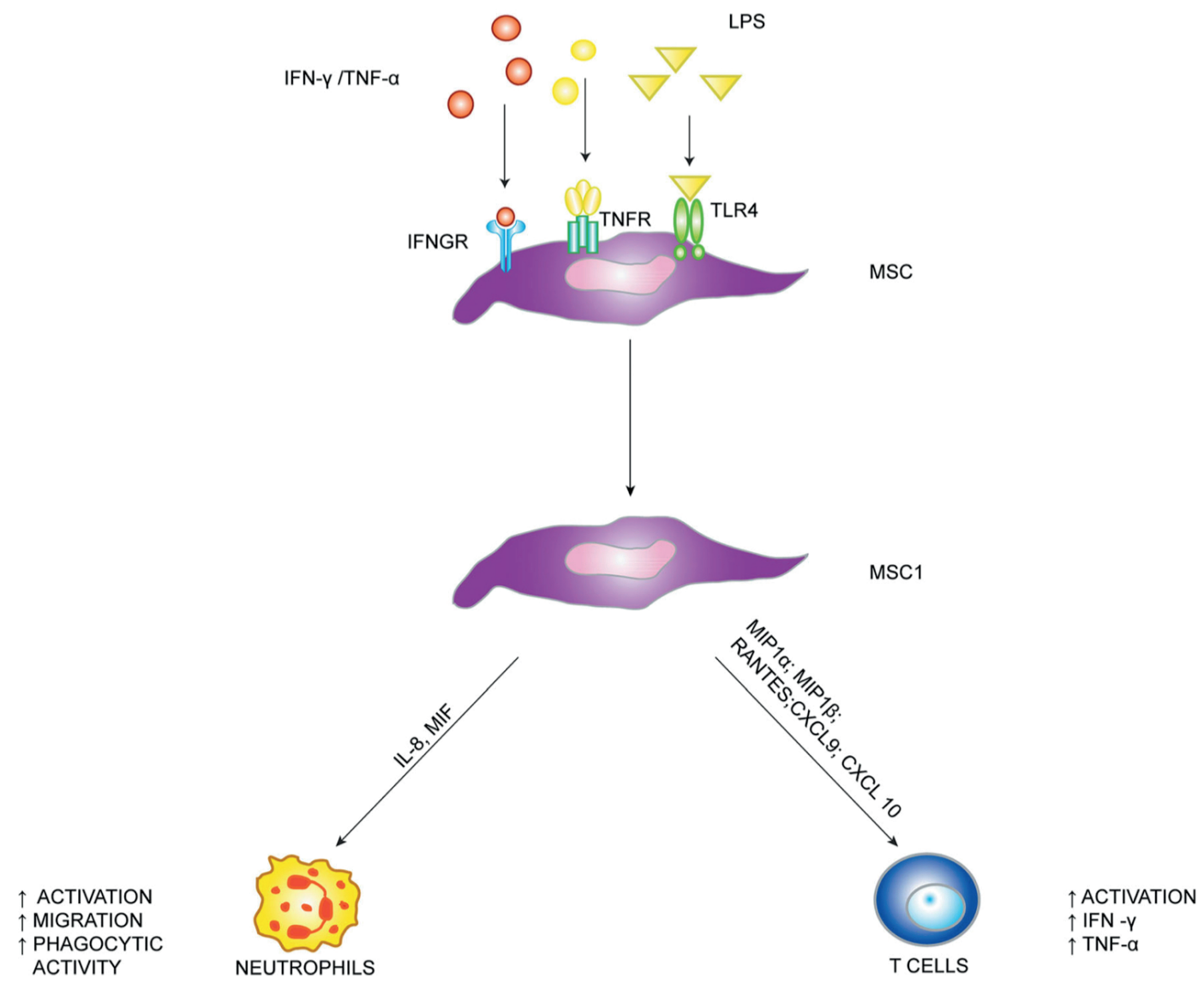

Figure 4. Pro-inflammatory activity of MSCs. During the early phase of inflammation, in the presence of low levels of IFN- $\gamma$ and TNF- $\alpha$ or by activation of TLR4 by low levels of LPS, MSCs may adopt a MSC1 phenotype.(145) MIF: migration inhibitory factor. (Adapted with permission from Springer). 
M1 macrophages are induced by TLR ligands (such as LPS) and IFN- $\gamma$. They express higher levels of CD86 and programmed death-ligand 1 (PD-L1).(157) M1 macrophages are characterized by the increased microbicidal activity and produce several proinflammatory mediators, such as inducible NOS, TNF- $\beta$, IL-1 $\beta$, IL-6, IL-12, and proteolytic enzymes.(158) They constitute the first line of defense against pathogens and promote Th1 polarization of $\mathrm{CD}^{+}$lymphocytes. Meanwhile, M2 macrophages are induced by Th2-type cytokines, such as IL-4 and IL-13. Tregs have also been implicated in induction process of M2 polarization, possibly through IL-10.(159) M2-like cells have been potrayed in different pathological conditions such as infections by intracellular bacteria or virus, allergy, diabetes, and cancer.(155,160) They are characterized by the expression of CD163, CD206, arginase 1, Fizz1 (which is found in inflammatory zone 1), and CD36. In addition, they secrete anti-inflammatory cytokines, such as TGF- $\beta$, IL-1 receptor antagonist, and IL-10. M2 macrophages have an essential role in the suppression of Th1 immune responses and the enhancement of tissue remodeling and Th2 response.(161) Macrophages with intermediate or overlapping phenotypes have also been reported. For instance, adipose tissue macrophages from obese mice have a mixed profile, with upregulation of several M1 and M2 gene transcripts.(162)

Kim and Hematti were the first to report that MSCs could polarize macrophages from the classic proinflammatory M1 phenotype, toward the antiinflammatory M2 phenotype.(132) They found that macrophages co-cultured with MSCs consistently showed a high level expression of markers for M2 macrophages. The resulting macrophages produced high levels of IL-10 and low levels of IL-12 and TNF- $\beta$. Functionally, macrophages which co-cultured with MSCs showed a higher level of phagocytic activity (Figure 5).(163) Other studies showed that MSC-mediated polarization of M2 macrophages depends on the secretion of soluble factors, including PGE2, TSG-6, IL-6, IDO, and TGF- $\beta 1 .(139,164,165)$

Through the prostaglandin receptors, MSCs can reprogram macrophages by cyclooxygenase-2 (COX2) activity increasing and PGE2 releasing. This macrophage activated produces antiinflammatory IL-10. Thus, inflammatory signals activating MSCs to secrete antiinflammatory protein, TSG-6.(134) TSG-6 interacted through the CD44 receptor on resident macrophages to decrease zymosan/TLR2 signaling, inducing a negative feedback loop, results beneficially in several infllmation, based disease models.(166,167)

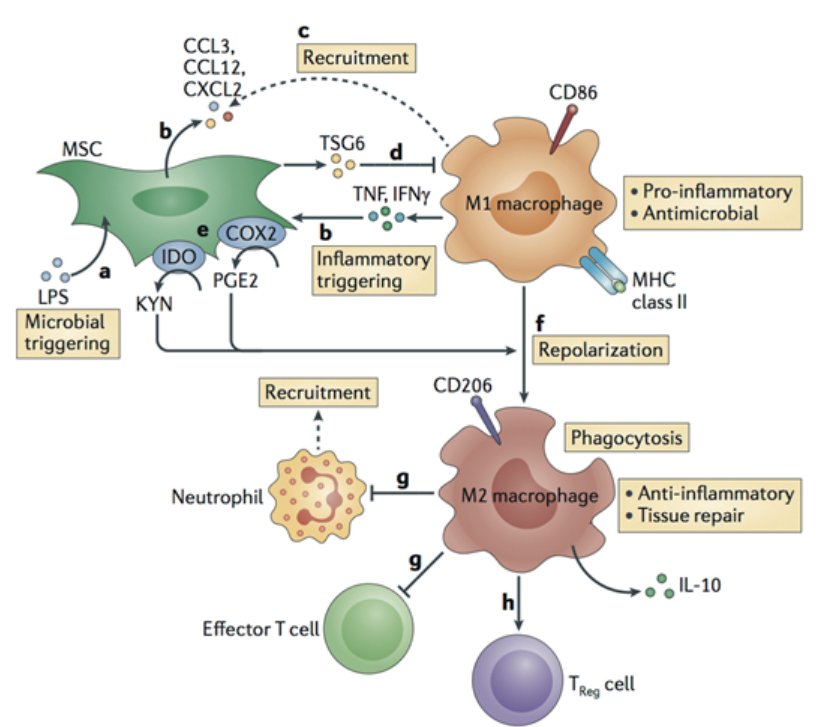

Figure 5. MSCs and phagocytes closely interact during inflammatory responses.(163) KYN: kynurenine; MHC: major histocompatibility complex. (Adapted with permission from Nature Publishing Group).

Either monocyte differentiation or IL-10-secreting M2 macrophages involved elevated IDO activity, and suppress T-cell proliferation in an IL-10-independent manner, thus amplifying the immunosuppressive effect generated by MSCs. By depleting monocytes from peripheral blood, another in vitro study found that monocytes were essential for MSC-induced Treg formation.(163) They suggest that MSCs promoted the survival of monocytes and induced differentiation toward M2 macrophages via unknown soluble factors. Then, M2 macrophages secreted high levels of IL-10 and chemokine C-C motif ligand (CCL)-18, which mediated the observed Treg induction.(167)

MSCs support macrophages with stimulating signals that encouraged its polarization inti M2 phenotype, explained many of the beneficial effects observed with administration of MSCs in animal models for many diseases. Further studies on the molecular mechanisms involved in the interaction between MSCs and macrophages will devote to a better understanding of MSCs biology and the optimal use of MSCs in the clinical practice.(167)

\section{MSCs Manage Wound Healing}

Chronic wound happens when there is a failure of injured skin to proceed through an orderly and timely process to produce anatomic and functional integrity. Causative factors include malnutrition and immunosuppression, and chronic wound is commonly seen as a consequence of diabetes mellitus and vascular compromise.(168) 
Chronic wound is a common and severe complication of diabetes and are associated with significant morbidity and mortality.(169) The impaired healing of diabetic wounds has been characterized by decreased production of chemokines (170), decreased angiogenesis (171), and an abnormal inflammatory response (172). Increasing evidence proposes that the persistent upregulation of inflammatory gene expression may plays role in the pathogenesis of the chronic diabetic wound through activation of inflammatory pathways.(173-175)

MSCs have been shown to have a role in woundhealing applications, including corrects diabetic wound healing in mice by accelerating epithelialization and increasing granulation tissue and angiogenesis. $(176,177)$ However, the exact molecular mechanisms of this correction have not been fully characterized. Current understanding formulating two main mechanisms of MSCs in enhancing wound healing, which are by releasing bioactive mediators necessary for healing, together with cytokines and growth factors, and differentiating themselves into the cell types required for the healing process of the wound.(168)

In addition to their differentiation ability, increasing evidence points to the ability of MSCs to secrete paracrine factors which modulate the local environment and stimulate wound healing.(178) Specifically, MSCs have been shown to significantly decrease the production of proinflammatory cytokines in the acute period when high levels can be deleterious to tissue and to upregulate them in the later regeneration phase.(179) Protein arrays have demonstrated that $\mathrm{CM}$ from MSC cultures contain various cytokines and chemokines such as IL-8, IL-6, TGF- $\beta$, and VEGF, all of which are essential to normal wound healing.(180) MSCs enhance the wound healing process by modulating angiogenesis and releasing proangiogenic factors such as VEGF and angiopoietin-1, reepithelialization, and granulation tissue formation. Other studies have demonstrated that intravenous (IV) injection in mice induced MSC trans-differentiation into keratinocytes, endothelial cells, and pericytes in cutaneous wounds. Application of human bone marrow MSCs to full thickness skin defects in mice in conjunction with IV MSC administration, can heal all wounds without a scar or retraction.(181)

Several miRNAs have been found in skin tissue and are thought to have a crucial role in a broad range of biologic processes, including the regulation of innate and adaptive immune responses.(182-184) MiR-146a has been defined as one of the key regulatory molecules in the inflammatory response. It can be induced by different proinflammatory stimuli, such as IL-1 $\beta$ and TNF- $\alpha .(185,186)$ MiRNA-146a has also been known to negatively regulate the innate immune response by targeting and repressing IL-1 receptorassociated kinase 1 (IRAK1) and TNFR-associated factor 6 (TRAF6).(186) As two key adapter molecules of the nuclear factor (NF)-KB pathway, IRAK1 and TRAF6 increase NF$\kappa \mathrm{B}$ activity, resulting in increased expression of the genes expressing IL-6 and IL-8 (187), which are key mediators of inflammation. Abnormal inflammation occurs in diabetic wounds and subsequent impairment in wound healing, in part was the responsibility of miR-146a, then MSC treatment for this diabetic wound-healing impairment is mediated by correction of abnormal miRNA-146a expression.(188)

\section{MSCs Manage Vascular Homeostasis}

Recently, there is increasing evidence indicating the relationship between tissue-specific stem/progenitor cells and vascular/perivascular niches $(189,190)$ as well as the presence of multipotent stem cells of vascular origin (190-193). Sacchetti, et al., showed that CD146 subendothelial stromal cells residing on the bone marrow sinusoidal wall not only self-renew and display vascular mural cell features but also form bone and establish the hematopoietic microenvironment.(40) Consequently, a hypothesis that blood vessels throughout the human body serve as a reservoir of multipotent precursor cells has been formulated.(194,195)

Using immunohistochemical assays and fluorescenceactivated cell sorting (FACS), three subpopulations of human blood-vessel-derived stem cells (hBVSC) has been successfully identified and purified from human blood vessels within human skeletal muscle, those are myogenic endothelial cells (MEC), pericytes, and adventitial cells (AC). These subpopulations each expressing a unique profile of cell surface antigens. Pericytes and ACs have also been isolated from several other human tissues such as fat and lung.(41,196-198) MECs, pericytes, and ACs all have common mesodermal multipotency and display typical MSC markers, suggesting their contributions to the heterogeneous MSCs entity.(197)

Pericytes are commonly regarded as a structural component of small blood vessels that regulate vascular contractility, stability, and integrity.(199-202) Pericytes also modulate endothelial cell proliferation/vascular remodeling and are involved in specialized vascular functions including blood-brain barrier and renal tubulovesicular coordination as well as several pathological conditions.(203-208) However, this particular cell population has not been well 
defined in most of human organs because of the lack of representative cell marker. Alkaline phosphatase (ALP) is another marker used to typify pericytes in human skeletal muscle. $(209,210) \alpha$ SMA, on the other hand, can be detected in pericytes encircling arterioles and venules but not in those surrounding most capillaries.(41) Pericytes in situ also express classic MSC markers: CD44, CD73, CD90 and CD105.(41)

Pericytes are involved in many different functions including maintenance of vascular contractility and permeability, control of vascular pressure, angiogenesis, immune defense, production of extracellular matrix (ECM) components, and keeping stability of vessels. In homeostasis, pericytes provide stabilization and nurturing signals to adjacent endothelial cells.(86,211,212) During angiogenic branching, pericytes are responsible for orchestrating new vessels to form a functionally efficient network.(213) Pericytes are thought to have regenerative properties of mesenchymal progenitor cells due to the ability to differentiate other cell types such as macrophages, myofibroblasts, osteoblasts, and adipocytes. $(208,214)$ This capacity suggests the involvement of pericytes in vascular remodelling and vascular injury healing. $(208,214)$

The capability to isolate subpopulations of hBVSCs marked a big progress to understand the heterogeneous MSC entity as well as their vascular/perivascular niches (Figure 6). Purified MECs, pericytes, and ACs exhibited robust reparative/regenerative capacities in many injured/ defective tissues, often outperforming unfractionated MSCs.(199)

MSCs exist in most adult tissues and are located near or within blood vessels. Although "perivascular" has been commonly used to describe such locations, increasing evidence points at the vessel wall as the exact location. Thus, "vascular stem cells (VSC)" is recommended as a more accurate term for MSCs. Two cell populations, called pericytes and adventitial progenitor cells (APC), likely were VSCs. The pericyte affirmation relies on the so-called pericyte-specific markers, though none of these markers is specific for pericyte. Moreover, pericytes appear to have a large differentiation capacity and too functionally diverse and sophisticated. On the other hand, APCs are more nave functionally and, therefore, more akin to being VSCs.(215)

\section{MSCs Manage Tissue Regeneration}

Regenerative medicine becoming an enormous hopes for patients with severe diseases without any effective treatment. This great expectation of tissue renewal

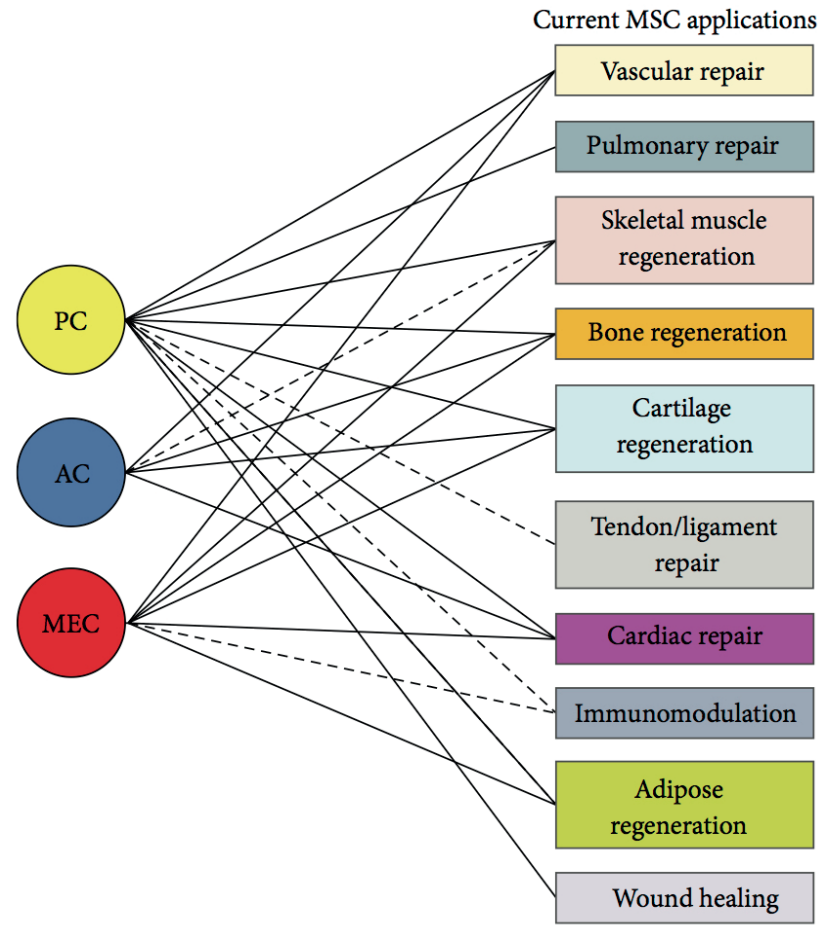

Figure 6. Potential translational applications of hBVSC subpopulations. The current translational applications of typical MSCs are summarized on the right. The current status of translational research for each hBVSC subset is outlined, whether the specific application has been tested or is presently under investigation.(199) PC: pericyte. (Adapted with permission from Hindawi).

conception was first formulated in the study of hematosis over a century ago, facilitated by a self-sustaining pool of stem cells.(216) in the beginning this renewal concept was thought to be limited only for blood cells but now it has been proven that the maintenance and replenishment of the cellular composition in almost all tissues in our body, including skin and intestinal epithelium, liver, skeletal muscles, and myocardium, occur through the proliferation and differentiation of the corresponding tissue-specific stem cells.(217)

Transplantation of MSCs stimulates the regeneration of tissues, including bone, skeletal muscles, myocardium, skin, liver, and peripheral nerves. This occurs owing to both the integration of transplanted MSCs into the recipient's tissues and the secretory activity of these cells.(218) It was showed that transplanted MSCs integrate the endothelial lining of growing capillaries and the periendothelial space of newly formed blood vessels, thereby stabilizing them.(217)

Many studies identified secretion of proangiogenic factors, including Adrenomedullin (219), Cyr61 (220), and IL-1 (221), and left ventricullar remodelling attenuation was observed through secretion of factors promoting 
either vasculogenesis $(222,223)$ or endothelial tube formation (224). Other MSCs secreted factors promoted mobilization of cardiac stem/progenitor cells $(219,225)$ or bone marrow-derived progenitor cells $(226,227)$; specifically, secreted frizzled related protein (SFRP)2 promoted MSC self-renewal and survival $(228,229)$. Cardiomyocytes survival improvement was mediated by at least four different secreted factors. $(219,230,231)$ Finally, anti-inflammatory factors like soluble TNFR1 (232) and TSG-6 (233) were identified.

MSCs are an important source of growth factors and cytokines, that participate in the regulation of tissue regeneration. Thus, MSCs produce factors in bone marrow that are necessary for the self-sustenance of hematopoietic stem cells and keep them in a niche. We can refer to such factors as the SDF- $1 \alpha, \mathrm{SCF}$, angiopoietin-1 and IL-7.(83) It was established that MSCs produce angiogenic and neurotrophic growth factors, including VEGF, HGF, basic fibroblast growth factor (bFGF), angiopoietin, nerve growth factor (NGF), brain-derived neurotrophic factor (BDNF), and glial cell line-derived neurotrophic factor (GDNF).(234,235) The angiogenic growth factors produced by MSCs in the transplantation region stimulate the division of endothelial cells, their migration, and the formation of blood vessels. In addition, the factors produced by MSCs promote the mobilization of endothelial progenitors from the bone marrow, which participate in the formation of new blood vessels. $(221,235)$ Simultaneously, the neurotrophic factors produced by MSCs stimulate both the growth and renewal of nerve endings.(234) Hence, MSCs can arbitrate the coordinated regulation of the growth of blood vessels and nerves during regeneration and remodeling of tissues (Figure 7).

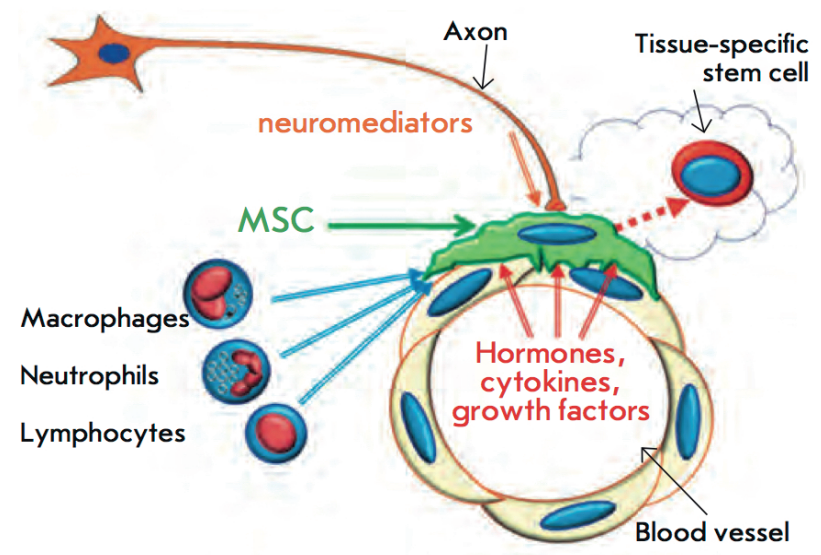

Figure 7. Hypothetic scheme showing the interaction of MSCs with axons, endothelial cells, leukocytes, and tissue-specific stem cells.(217) (Adapted with permission from Park-media).
Interestingly, the potential of MSCs to contribute to tissue repair has been found largely dependent on their secretory capacity rather than their differentiation capacity. Researches have mostly focused on the secretion of cytokines and growth factors by MSCs. However, recent data offers that the therapeutic effect of MSCs secretome can be partly due to secreted micro vesicles (MV), which can mirror the phenotype of their parent cells.(236)

Cell-to-cell communication is required to insure proper coordination among different cell types within tissues. Cells may communicate by soluble factors (237), adhesion molecule-mediated cell-to-cell interactions including cytonemes that connect neighboring cells enabling ligandreceptor-mediated transfer of surface-associated molecules, or by tunneling nanotubules that establish conduits between cells, allowing the transfer of not only surface molecules but also cytoplasmic components $(238,239)$. Recent studies have suggested that cells may also communicate by circular membrane fragments, namely MV.(240) This concept is based on the founding that MVs are released from a given cell type may interact via specific receptor ligands with other cells, leading to target cell stimulation directly or by transferring surface receptors. $(241,242)$ This implicates that MVs interact only with target cells that specifically recognize rather than just with any cell present in the microenvironment.(243)

The finding of paracrine features of MSCs really open a new dimension to the therapeutic applications of MSCs in regenerative medicine, and many limitation and safety concerns in MSCs transplantation could be mitigated.(244) recent studies suggested a bidirectional exchange of genetic information between stem and injured cells, and this gene products transfer from injured cells to stem cells explain how the stem cell changes functional and phenotypic without the need of transdifferentiation into tissue cells. On the contrary, transfer of gene products from stem cells may reprogram injured cells to repair damaged tissues.(245)

MSCs and stem/pericytes cells could be seen as sensory, highly receptive to local biologic information; synthetic, capable of producing biomolecules in response to the received information; and secretory, capable of fabricating and delivering those biomolecules; units characterized by their innate therapeutic potential.(148) These units or cells have acquired these unique capabilities through evolution and provide the organism with unique, highly adaptive, survival characteristics. In the analogy to a computer proposed by Hariri, these stem and progenitor cells have a design in which the nucleus houses the operational software, resident in the DNA of the chromosomes, at the 
core of a complex processor and complex information transferring apparatus within the cell cytoplasm.(246)

Thus, the therapeutic output of cell-based therapies relies both on the docking or sensing and on the cellular output in the form of secreted factors (247), which exert their effects in our genomically controlled endocrine or paracrine regeneration/repair ability. By the time humans reach the age of 40-50 years, this regenerative and repair potential is greatly diminished and accounts for "late-onset" diseases or tissue dysfunction. The medical challenge is to find how to optimize the remaining innate regenerative potential and to understand how to supplement these unique functionalities.(38)

On the assumption that MSC is undoubtedly roles as the managers of site-specific tissue regeneration, their presence, number, proper activation, coordinated and dynamic function surely have a profound impact on injury and disease progression. Thus, the medicinal activity of MSC is dependent on the tissue management and site of injury aspects, with respect to the therapeutic capacity of either endogenous or exogenously supplied MSCs. This infers that MSCs are intrinsically curative and that their therapeutic effectiveness solely depends on the "when, where, and how" of their delivery or presentation at sites of injury, disease, or regeneration.(248)

\section{Conclusion}

The multipotent MSC, now renamed the medicinal signaling cell, predominantly raises from pericytes released from broken and inflamed blood vessels and seems to function as both an immunomodulatory and a regeneration mediator. MSCs are being tested for their management capabilities to produce therapeutic outcomes in more than 480 clinical trials for a wide range of clinical conditions. Local MSCs function by managing the body's primary repair and regeneration activities. MSCs can be obtained from many tissues in human body, either allogeneic or autologous origin, and have a highly plasticity features that allows MSCs to transform into many type of cells such as their capacity to differentiate into adipocytes, osteocytes, chondrocytes, and neuronal/glial cells. Together with its paracrine features, MSC-based therapy has the potential to change how health care is delivered. These medicinal cells have a capability of sensing their surroundings, and with their complex signaling circuitry, they organize site-specific regenerative responses smartly as if these therapeutic cells were well-programmed modern computers. Given these facts, it appears that we are entering a new age of cellular medicine. The innate regenerative capacity of almost every host tissue has never been properly managed and MSCs appear to be assisting the host tissue to maximize its intrinsic regenerative capacity. The Medicine of Tomorrow may be the management of MSCs to optimize the body's very powerful and everchanging intrinsic regenerative potential. The reason for reviewing the above is to emphasize the emerging theme that MSCs appear to be assisting the host tissue to maximize its intrinsic regenerative capacity. The local management of the immune cells and the tissue specific progenitors appears to be accomplished by very few, locally situated, and shortlived MSCs. This innate regenerative capacity of almost every host tissue has never been properly managed except, perhaps, in orthopedics where the vigorous regenerative and repair capacity of bone (maybe through local MSCs) is managed by orthopedic physician interface. The Medicine of Tomorrow may be the management of MSCs to optimize the body's very powerful and ever changing intrinsic regenerative potential.

\section{References}

1. Friedenstein AJ, Chailakhyan RK, Latsinik NV, Panasyuk AF, Keiliss-Borok IV. Stromal cells responsible for transferring the microenvironment of the hemopoietic tissues: cloning in vitro and retransplantation in vivo. Transplantation. 1974; 17: 331-40.

2. Kang SG, Shinojima N, Hossain A, Gumin J, Yong RL, Colman H, et al. Isolation and perivascular localization of mesenchymal stem cells from mouse brain. Neurosurgery. 2010; 67: 711-20.

3. Najimi M, Khuu DN, Lysy PA, Jazouli N, Abarca J, Sempoux C, et al. Adult-derived human liver mesenchymal-like cells as a potential progenitor reservoir of hepatocytes? Cell Transplant. 2007; 16: 71728.

4. Lama VN, Smith L, Badri L, Flint A, Andrei AC, Murray S, et al. Evidence for tissue-resident mesenchymal stem cells in human adult lung from studies of transplanted allografts. J Clin Invest. 2007; 117: 989-96.

5. Wang HS, Hung SC, Peng ST, Huang CC, Wei HM, Guo YJ, et al. Mesenchymal stem cells in the Wharton's jelly of the human umbilical cord. Stem Cells. 2004; 22: 1330-7.

6. Zuk PA, Zhu M, Ashjian P, De Ugarte DA, Huang JI, Mizuno H, et al. Human adipose tissue is a source of multipotent stem cells. Mol Biol Cell. 2002; 13: 4279-95.

7. Lina Y, Wijaya A. Novel sources of fetal stem cells for future regenerative medicine. Indones Biomed J. 2012; 4: 3-11.

8. Lina Y, Wijaya A. Adipose-derived stem cells for future regenerative system medicine. Indones Biomed J. 2012; 4: 59-72.

9. Pittenger MF, Mackay AM, Beck SC, Jaiswal RK, Douglas R, Mosca JD, et al. Multilineage potential of adult human mesenchymal stem cells. Science. 1999; 284: 143-7.

10. Jiang Y, Jahagirdar BN, Reinhardt RL, Schwartz RE, Keene CD, Ortiz-Gonzalez XR, et al. Pluripotency of mesenchymal stem cells derived from adult marrow. Nature. 2002; 418: 41-9. 
11. Mafi R, Hindocha S, Mafi P, Griffin M, Khan WS. Sources of adult mesenchymal stem cells applicable for musculoskeletal applications: a systematic review of the literature. Open Orthop J. 2011; 5 (Suppl 2): 242-8.

12. Quevedo HC, Hatzistergos KE, Oskouei BN, Feigenbaum GS, Rodriguez JE, Valdes D, et al. Allogeneic mesenchymal stem cells restore cardiac function in chronic ischemic cardiomyopathy via trilineage differentiating capacity. Proc Natl Acad Sci USA. 2009; 106: $14022-7$.

13. Aggarwal S, Pittenger MF. Human mesenchymal stem cells modulate allogeneic immune cell responses. Blood. 2005; 105: 1815-22.

14. Caplan AI, Dennis JE. Mesenchymal stem cells as trophic mediators. J Cell Biochem. 2006; 98: 1076-84.

15. Waszak P, Alphonse R, Vadivel A, Ionescu L, Eaton F, Thébaud B. Preconditioning enhances the paracrine effect of mesenchymal stem cells in preventing oxygen-induced neonatal lung injury in rats. Stem Cells Dev. 2012; 21: 2789-97.

16. Du Z, Wei C, Cheng K, Han B, Yan J, Zhang M, et al. Mesenchymal stem cell-conditioned medium reduces liver injury and enhances regeneration in reduced-size rat liver transplantation. J Surg Res. 2013; 183: 907-15.

17. Lavoie JR, Rosu-Myles M. Uncovering the secretes of mesenchymal stem cells. Biochimie. 2013; 95: 2212-21.

18. Pittenger MF, Le Blanc K, Phinney DG, Chan JK. MSCs: scientific support for multiple therapies. Stem Cell Int. 2015; 2015: 280572.

19. Dominici M, Le Blanc K, Mueller I, Slaper-Cortenbach I, Marini F, Krause D, et al. Minimal criteria for defining multipotent mesenchymal stromal cells: The International Society for Cellular Therapy position statement. Cytotherapy. 2006; 8: 315-7.

20. Brooke G, Cook M, Blair C, Han R, Heazlewood C, Jones B, et al. Therapeutic applications of mesenchymal stromal cells. Semin Cell Dev Biol. 2007; 18: 846-58.

21. Bluguermann $\mathrm{C}, \mathrm{Wu}$ L, Petrigliano F, McAllister D, Miriuka S, Evseenko DA. Novel aspects of parenchymal-mesenchymal interactions: from cell types to molecules and beyond. Cell Biochem Funct. 2013; 31: 271-80.

22. Chen J, Li Y, Wang L, Zhang Z, Lu D, Lu M, et al. Therapeutic benefit of intravenous administration of bone marrow stromal cells after cerebral ischemia in rats. Stroke. 2001; 32: 1005-11.

23. Ortiz LA, Gambelli F, McBride C, Gaupp D, Baddoo M, Kaminski $\mathrm{N}$, et al. Mesenchymal stem cell engraftment in lung is enhanced in response to bleomycin exposure and ameliorates its fibrotic effects. Proc Natl Acad Sci USA. 2003; 100: 8407-11.

24. Park KS, Jung KH, Kim SH, Kim KS, Choi MR, Kim Y, et al. Functional expression of ion channels in mesenchymal stem cells derived from umbilical cord vein. Stem Cells. 2007; 25: 2044-52.

25. Rojas M, Xu J, Woods CR, Mora AL, Spears W, Roman J, et al. Bone marrow-derived mesenchymal stem cells in repair of the injured lung. Am J Respir Cell Mol Biol. 2005; 33: 145-52.

26. Baraniak PR, McDevitt TC. Stem cell paracrine actions and tissue regeneration. Regen Med. 2010; 5: 121-43.

27. Kassis I, Vaknin-Dembinsky A, Karussis D. Bone marrow mesenchymal stem cells: agents of immunomodulation and neuroprotection. Curr Stem Cell Res Ther. 2011; 6: 63-8.

28. Dittmer J, Leyh B. Paracrine effects of stem cells in wound healing and cancer progression. Int J Oncol. 2014; 44: 1789-98.

29. Caplan AI. What's in a name? Tissue Eng Part A. 2010; 16: 2415-7.

30. Caplan AI, Correa D. The MSC: an injury drugstore. Cell Stem Cell. 2011; 9: 11-5.

31. Caplan AI. MSCs: the new medicine. In: Vertes A, editor. Stem Cells in Regenerative Medicine: Science, Regulation and Business Strategies. New York: John Wiley \& Sons; 2016. p.415-22.
32. da Silva Meirelles L, Caplan AI, Nardi NB. In search of the in vivo identity of mesenchymal stem cells. Stem Cells. 2008; 26: 2287-99.

33. Bianco P, Riminucci M, Gronthos S, Robey PG. Bone marrow stromal stem cells: nature, biology, and potential applications. Stem Cells. 2001; 19: 180-92.

34. Shehadah A, Chen J, Pal A, He S, Zeitlin A, Cui X, et al. Human placenta-derived adherent cell treatment of experimental stroke promotes functional recovery after stroke in young adult and older rats. PLoS One. 2014; 9: e86621.

35. Penn MS, Ellis S, Gandhi S, Greenbaum A, Hodes Z, Mendelsohn FO, et al. Adventitial delivery of an allogeneic bone marrowderived adherent stem cell in acute myocardial infarction: phase I clinical study. Circ Res. 2012; 110: 304-11.

36. See F, Seki T, Psaltis PJ, Sondermeijer HP, Gronthos S, Zannettino AC, et al. Therapeutic effects of human STRO-3-selected mesenchymal precursor cells and their soluble factors in experimental myocardial ischemia. J Cell Mol Med. 2011; 15: 2117-29.

37. Gir P, Oni G, Brown SA, Mojallal A, Rohrich RJ. Human adipose stem cells: current clinical applications. Plast Reconstr Surg. 2012; 129: $1277-90$.

38. Caplan AI, Hariri R. Body management: mesenchymal stem cells control the internal regenerator. Sem Cell Transl Med. 2015; 4: 695701.

39. Caplan AI. All MSCs are pericytes? Cell Stem Cell. 2008; 3: 229-30.

40. Sacchetti B, Funari A, Michienzi S, Di Cesare S, Piersanti S, Saggio I, et al. Self-renewing osteoprogenitors in bone marrow sinusoids can organize a hematopoietic microenvironment. Cell. 2007; 131: 324-36.

41. Crisan M, Yap S, Casteilla L, Chen CW, Corselli M, Park TS, et al. A perivascular origin for mesenchymal stem cells in multiple human organs. Cell Stem Cell. 2008; 3: 301-13.

42. Penn MS, Anwaruddin S, Nair R, Ellis S. From mice to men: commonalities in physiology for stem cell-based cardiac repair. J Am Coll Cardiol. 2009; 54: 2287-9.

43. Haynesworth SE, Baber MA, Caplan AI. Cytokine expression by human marrow-derived mesenchymal progenitor cells in vitro: effects of dexamethasone and IL-1alpha. J Cell Physiol. 1996; 166: 585-92.

44. da Silva Meirelles L, Chagastelles PC, Nardi NB. Mesenchymal stem cells reside in virtually all post-natal organs and tissues. J Cell Sci. 2006; 119: 2204-13.

45. Campagnoli C, Roberts IA, Kumar S, Bennett PR, Bellantuono I, Fisk NM. Identification of mesenchymal stem/progenitor cells in human first-trimester fetal blood, liver, and bone marrow. Blood. 2001; 98 : 2396-402.

46. Kean TJ, Lin P, Caplan AI, Dennis JE. MSCs: delivery routes and engraftment, cell-targeting strategies, and immune modulation. Stem Cells Int. 2013; 2013: 732742.

47. Singer NG, Caplan AI. Mesenchymal stem cells: mechanisms of inflammation. Annu Rev Pathol. 2011; 6: 457-78.

48. Li Y, Chen J, Chen XG, Wang L, Gautam SC, Xu YX, et al. Human marrow stromal cell therapy for stroke in rat: neurotrophins and functional recovery. Neurology. 2002; 59: 514-23.

49. Siegel G, Krause P, Wöhrle S, Nowak P, Ayturan M, Kluba T, et al. Bone marrow-derived human mesenchymal stem cells express cardiomyogenic proteins but do not exhibit functional cardiomyogenic differentiation potential. Stem Cells Dev. 2012; 21: 2457-70.

50. van Koppen A, Joles JA, van Balkom BW, Lim SK, de Kleijn D, Giles RH, et al. Human embryonic mesenchymal stem cell-derived conditioned medium rescues kidney function in rats with established chronic kidney disease. PLoS One. 2012; 7: e38746. 
51. van Poll D, Parekkadan B, Cho CH, Berthiaume F, Nahmias Y, Tilles $\mathrm{AW}$, et al. Mesenchymal stem cell-derived molecules directly modulate hepatocellular death and regeneration in vitro and in vivo. Hepatology. 2008; 47: 1634-43.

52. Caplan AI. Why are MSCs therapeutic? New data: new insight. J Pathol. 2009; 217: 318-24.

53. Prockop DJ. Marrow stromal cells as stem cells for nonhematopoietic tissues. Science.1997; 276: 71-4.

54. Togel F, Weiss K, Yang Y, Hu Z, Zhang P, Westenfelder C. Vasculotropic, paracrine actions of infused mesenchymal stem cells are important to the recovery from acute kidney injury. Am J Physiol Renal Physiol. 2007; 292: F1626-35.

55. Hocking AM, Gibran NS. Mesenchymal stem cells: paracrine signaling and differentiation during cutaneous wound repair. Exp Cell Res. 2010; 316: 2213-9.

56. Eggenhofer E, Benseler V, Kroemer A, Popp FC, Geissler EK, Schlitt $\mathrm{HJ}$, et al. Mesenchymal stem cells are short-lived and do not migrate beyond the lungs after intravenous infusion. Front Immunol. 2012; 3: 297.

57. Liu XB, Chen $\mathrm{H}$, Chen $\mathrm{HQ}$, Zhu MF, Hu XY, Wang YP, et al. Angiopoietin-1 preconditioning enhances survival and functional recovery of mesenchymal stem cell transplantation. J Zhejiang Univ Sci B. 2012; 13: 616-23.

58. Eggenhofer E, Luk F, Dahlke MH, Hoogduijn J. The life and fate of mesenchymal stem cells. Front Immunol. 2014; 5: 148.

59. Singer M. The trophic quality of the neuron: some theoretical considerations. Prog Brain Res. 1964; 13: 228-32.

60. Singer M. The trophic quality of the neuron: some theoretical considerations. In: Singer M, Schade JP, editors. Progress in Brain Research. Amsterdam: Elsevier; 1964.

61. Singer M. Neurotrophic control of limb regeneration in the newt. Ann NY Acad Sci. 1974; 228: 308-22.

62. Mangi AA, Noiseux N, Kong D, He H, Rezvani M, Ingwall JS, et al. Mesenchymal stem cells modified with akt prevent remodeling and restore performance of infarcted hearts. Nature Med. 2003; 9: 1195201.

63. Tang YL, Zhao Q, Zhang YC, Cheng L, Liu M, Shi J, et al. Autologous mesenchymal stem cell transplantation induce VEGF and neovascularization in ischemic myocardium. Regul Pept. 2004; 117: 3-10.

64. Sinsicalco D, Sullo N, Maione S, Rossi F, D’ A gostino B. Stem cell therapy: the great promise in lung disease. Ther Adv Respir Dis. 2008; 2: 173-7.

65. Chen MF, Lin CT, Chen WC, Yang CT, Chen CC, Liao SK, et al. The sensitivity of human mesenchymal stem cells to ionizing radiation. Int J Radiat Oncol Biol Phys. 2006; 66: 244 -53.

66. Bai L, Caplan AI, Lennon DL, Miller RH. Human mesenchymal stem cell signals regulate neural stem cell fate. Neurochem Res. 2007; 32: $353-62$.

67. Estes BT, Wu AW, Guilak F. Potent induction of chondrocytic differential of human adipose-derived adult stem cells by bone morphogenetic protein 6. Arthrit Rheum. 2006; 54: 1222-32.

68. da Silva Meirelles L, Sand TT, Harman RJ, Lennon DP, Caplan AI. MSC frequency correlates with blood vessel density in equine adipose tissue. Tiss Eng A. 2009; 15: 221-9.

69. Bianco P, Cao X, Frenette PS, Mao JJ, Robey PG, Simmons PJ, et al. The meaning, the sense and the significance: translating the science of mesenchymal stem cells into medicine. Nat Med. 2013; 19: 3542.

70. Bianco P. Bone and the hematopoietic niche: a tale of two stem cells. Blood. 2011; 117: 5281-8.
71. Au P, Tam J, Fukumura D, Jain RK. Bone marrow-derived mesenchymal stem cells facilitate engineering of long-lasting functional vasculature. Blood. 2008; 111: 4551-8.

72. Melero-Martin JM, De Obaldia ME, Kang SY, Khan ZA, Yuan L, Oettgen $\mathrm{P}$, et al. Engineering robust and functional vascular networks in vivo with human adult and cord blood-derived progenitor cells. Circ Res. 2008; 103: 194-202.

73. Moioli EK, Clark PA, Chen M, Dennis JE, Erickson HP, Gerson SL, et al. Synergistic actions of hematopoietic and mesenchymal stem/ progenitor cells in vascularizing bioengineered tissues. PLoS ONE. 2008; 3: e3922

74. Crisan M, Yap S, Casteilla L, Chen CW, Corselli M, Park TS, et al. A perivascular origin for mesenchymal stem cells in multiple human organs. Cell Stem Cell. 2008; 3: 301-13.

75. Daquinag AC, Zhang Y, Amaya-Manzanares F, Simmons PJ, Kolonin MG. An isoform of decorin is a resistin receptor on the surface of adipose progenitor cells. Cell Stem Cell. 2011; 9: 74-86

76. Berg RD. The indigenous gastrointestinal microflora. Trends Microbiol. 1996; 4: 430-5.

77. Savage DC. Microbial ecology of the gastrointestinal tract. Annu Rev Microbiol . 1977; 31: 107-33.

78. Serhan CN, Chiang N, Van Dyke TE. Resolving inflammation: dua anti-inflammatory and pro-resolution lipid mediators. Nat Rev Immunol. 2008; 8: 349-61.

79. Gordon S, Martinez FO. Alternative activation of macrophages: mechanism and functions. Immunity. 2010; 32: 593-604.

80. Izcue A, Coombes JL, Powrie F. Regulatory lymphocytes and intestinal inflammation. Annu Rev Immunol. 2009; 27: 313-38.

81. Wan YY. Regulatory T cells: immune suppression and beyond. Cell Mol Immunol. 2010; 7: 204-10.

82. Bianco P, Sacchetti B, Riminucci M. Osteoprogenitors and the hematopoietic microenvironment. Best Pract Res Clin Haematol. 2011; 24: 37-47.

83. Méndez-Ferrer S, Michurina TV, Ferraro F, Mazloom AR, Macarthur BD, Lira SA, et al. Mesenchymal and haematopoietic stem cells form a unique bone marrow niche. Nature. 2010; 466: 829-34.

84. Ganz T. Epithelia: not just physical barriers. Proc Natl Acad Sci USA. 2002; 99: 3357-8.

85. Signore M, Cerio AM, Boe A, Pagliuca A, Zaottini V, Schiavoni I, et al. Identity and ranking of colonic mesenchymal stromal cells. J Cell Physiol. 2012; 227: 3291-300.

86. Diaz-Flores L, Gutiérrez R, Madrid JF, Varela H, Valladares F, Acosta E, et al. Pericytes: Morphofunction, interactions and pathology in a quiescent and activated mesenchymal cell niche. Histol Histopathol. 2009; 24: 909-69.

87. Brittan M, Wright NA. Stem cell in gastrointestinal structure and neoplastic development. Gut. 2004; 53: 899-910.

88. Meirelles Lda S, Fontes AM, Covas DT, Caplan AI. Mechanisms involved in the therapeutic properties of mesenchymal stem cells. Cytokine Growth Factor Rev. 2009; 20: 419-27.

89. Brown SL, Riehl TE, Walker MR, Geske MJ, Doherty JM, Stenson WF, et al. Myd88-dependent positioning of Ptgs2-expressing stromal cells maintains colonic epithelial proliferation during injury. J Clin Invest. 2007; 117: 258-69.

90. Goessling W, North TE, Loewer S, Lord AM, Lee S, Stoick-Cooper $\mathrm{CL}$, et al. Genetic interaction of PGE2 and Wnt signaling regulates developmental specification of stem cells and regeneration. Cell 2009; 136: 1136-47.

91. Krampera M, Cosmi L, Angeli R, Pasini A, Liotta F, Andreini A, et $a l$. Role for interferon-gamma in the immunomodulatory activity of human bone marrow mesenchymal stem cells. Stem Cells. 2006; 24: $386-98$ 
92. Krampera M, Sartoris S, Liotta F, Pasini A, Angeli R, Cosmi L, et al. Immune regulation by mesenchymal stem cells derived from adult spleen and thymus. Stem Cells Dev. 2007; 16: 797-810.

93. Groh ME, Maitra B, Szekely E, Koc ON. Human mesenchymal stem cells require monocyte-mediated activation to suppress alloreactive T cells. Exp Hematol. 2005; 33: 928-34.

94. Di Nicola M, Carlo-Stella C, Magni M, Milanesi M, Longoni PD, Matteucci $\mathrm{P}$, et al. Human bone marrow stromal cells suppress T-lymphocyte proliferation induced by cellular or nonspecific mitogenic stimuli. Blood. 2002; 99: 3838-43.

95. Liu H, Kemeny DM, Heng BC, Ouyang HW, Melendez AJ, Cao T. The immunogenicity and immunomodulatory function of osteogenic cells differentiated from mesenchymal stem cells. J Immunol. 2006; 176: 2864-71.

96. Tse WT, Pendleton JD, Beyer WM, Egalka MC, Guinan EC. Suppression of allogeneic T-cell proliferation by human marrow stromal cells: implications in transplantation. Transplantation. 2003; 75: 389-97.

97. Meisel R, Zibert A, Laryea M, Gobel U, Daubener W, Dilloo D. Human bone marrow stromal cells inhibit allogeneic T-cell responses by indoleamine 2,3-dioxygenase mediated tryptophan degradation. Blood. 2004; 103: 4619-21.

98. Xu G, Zhang Y, Zhang L, Ren G, Shi Y. The role of IL-6 in inhibition of lymphocyte apoptosis by mesenchymal stem cells. Biochem Biophys Res Commun. 2007; 361: 745-50.

99. Djouad F, Charbonnier LM, Bouffi C, Louis-Plence P, Bony C, Apparailly F, et al. Mesenchymal stem cells inhibit the differentiation of dendritic cells through an interleukin-6-dependent mechanism. Stem Cells. 2007; 25: 2025-32.

100. Zhang W, Ge W, Li C, You S, Liao L, Han Q, et al. Effects of mesenchymal stem cells on differentiation, maturation, and function of human monocyte-derived dendritic cells. Stem Cells Dev. 2004; 13: 263-71.

101. Jiang XX, Zhang Y, Liu B, Zhang SX, Wu Y, Yu XD, et al. Human mesenchymal stem cells inhibit differentiation and function of monocyte-derived dendritic cells. Blood. 2005; 105: 4120-6.

102. Beyth S, Borovsky Z, Mevorach D, Liebergall M, Gazit Z, Aslan H, et al. Human mesenchymal stem cells alter antigen-presenting cell maturation and induce T-cell unresponsiveness. Blood. 2005; 105: 2214-9.

103. Klyushnenkova E, Mosca JD, Zernetkina V, Majumdar MK, Beggs KJ, Simonetti DW, et al. T cell responses to allogeneic human mesenchymal stem cells: immunogenicity, tolerance, and suppression. J Biomed Sci. 2005; 12: 47-57.

104. Potian JA, Aviv H, Ponzio NM, Harrison JS, Rameshwar P. Vetolike activity of mesenchymal stem cells: functional discrimination between cellular responses to alloantigens and recall antigens. J Immunol. 2003; 171: 3426-34.

105. Sato K, Ozaki K, Oh I, Meguro A, Hatanaka K, Nagai T, et al. Nitric oxide plays a critical role in suppression of T-cell proliferation by mesenchymal stem cells. Blood. 2007; 109: 228-34.

106. Cbannes D, Hill M, Merieau E, Rossignol J, Brion R, Soulillou JP, et al. A role for heme oxygenase-1 in the immunosuppressive effect of adult rat and human mesenchymal stem cells. Blood. 2007; 110: 3691-4.

107. Selmani Z, Naji A, Zidi I, Favier B, Gaiffe E, Obert L, et al. Human leukocyte antigen-G5 secretion by human mesenchymal stem cells is required to suppress T-lymphocyte and natural killer function and to induce CD4+CD25highFOXP3+ regulatory T cells. Stem Cells. 2008; 26: 212-22.

108. Oh I, Ozaki K, Sato K, Meguro A, Tatara R, Hatanaka K, et al. Interferon-gamma and $\mathrm{NF}-\mathrm{kappaB}$ mediate nitric oxide production by mesenchymal stromal cells. Biochem Biophys Res Commun. 2007; 355: 956-62.

109. Haniffa MA, Collin MP, Buckley CD, Dazzi F. Mesenchymal stem cells: the fibroblasts' new clothes? Haematologica. 2009; 94: 25863.

110. Le Blanc K, Tammik L, Sundberg B, Haynesworth SE, Ringden O. Mesenchymal stem cells inhibit and stimulate mixed lymphocyte cultures and mitogenic responses independently of the major histocompatibility complex. Scand J Immunol. 2003; 57: 11-20.

111. Krampera M, Glennie S, Dyson J, Scott D, Laylor R, Simpson E, et al. Bone marrow mesenchymal stem cells inhibit the response of naive and memory antigen-specific $\mathrm{T}$ cells to their cognate peptide. Blood. 2003; 101: 3722-9.

112. Glennie S, Soeiro I, Dyson PJ, Lam EW, Dazzi F. Bone marrow mesenchymal stem cells induce division arrest anergy of activated T cells. Blood. 2005; 105: 2821-7.

113. Ghannam S, Pene J, Torcy-Moquet G, Jorgensen C, Yssel H. Mesenchymal stem cells inhibit human Th17 cell differentiation and function and induce a $\mathrm{T}$ regulatory cell phenotype. J Immunol. 2010; 185: 302-12.

114. Prigione I, Benvenuto F, Bocca P, Battistini L, Uccelli A, Pistoia V. Reciprocal interactions between human mesenchymal stem cells and gammadelta $\mathrm{T}$ cells or invariant natural killer T cells. Stem Cells. 2009; 27: 693-702.

115. Corcione A, Benvenuto F, Ferretti E, Giunti D, Cappiello V, Cazzanti F, et al. Human mesenchymal stem cells modulate B cell functions. Blood. 2006; 107: 367-72.

116. Spaggiari GM, Capobianco A, Becchetti S, Mingari MC, Moretta L. Mesenchymal stem cell-natural killer cell interactions: evidence that activated NK cells are capable of killing MSCs, whereas MSCs can inhibit IL-2-induced NK-cell proliferation. Blood. 2006; 107 : 1484-90.

117. Ramasamy R, Fazekasova H, Lam EW, Soeiro I, Lombardi G, Dazzi F. Mesenchymal stem cells inhibit dendritic cell differentiation and function by preventing entry into the cell cycle. Transplantation. 2007; 83: 71-6.

118. Raffaghello L, Bianchi G, Bertolotto M, Montecucco F, Busca A, Dallegri F, et al. Human mesenchymal stem cells inhibit neutrophil apoptosis: a model for neutrophil preservation in the bone marrow niche. Stem Cells. 2008; 26: 151-62.

119. Puissant B, Barreau C, Bourin P, Clavel C, Corre J, Bousquet C, et al. Immunomodulative effect of human adipose tissue-derived adult stromal cells: comparison with bone marrow mesenchymal stem cells. Br J Haematol. 2005; 129: 118-29.

120. Le Blanc K, Tammik C, Rosendahl K, Zetterberg E, Ringden O. HLA expression and immunologic properties of differentiated and undifferentiated mesenchymal stem cells. Exp Hematol. 2003; 31: 890-6.

121. Jones S, Horwood N, Cope A, Dazzi F. The antiproliferative effect of mesenchymal stem cells is a fundamental property shared by all stromal cells. J Immunol. 2007; 179: 2824-31.

122. Haniffa MA, Wang XN, Holtick U, Rae M, Isaacs JD, Dickinson AM, et al. Adult human fibroblasts are potent immunoregulatory cells and functionally equivalent to mesenchymal stem cells. J Immunol. 2007; 179: 1595-604.

123. Chen GY, Nuñez G. Sterile inflammation: sensing and reacting to damage. Nat Rev Immunol. 2010; 10: 826-37.

124. Rock KL, Latz E, Ontiveros F, Kono H. The sterile inflammatory response. Annu Rev Immunol. 2010; 28: 321-42.

125. Eigenbrod T, Park JH, Harder J, Iwakura Y, Núñez G. Cutting edge: critical role for mesothelial cells in necrosis-induced inflammation through the recognition of IL-1alpha released from dying cells. J Immunol. 2008; 181: 8194-8. 
126. Soehnlein O, Lindbom L. Phagocyte partnership during the onset and resolution of inflammation. Nat Rev Immunol. 2010; 10: 427-39.

127. Prockop DJ, Oh JY. Mesenchymal stem/stromal cells (MSCs): role as guardians of inflammation. Mol Ther. 2012; 20: 14-20.

128. Spaggiari GM, Moretta L. Cellular and molecular interactions of mesenchymal stem cells in innate immunity. Immunol Cell Biol. 2013; 91; 27-31.

129. Nauta AJ, Kruisselbrink AB, Lurvink E, Willemze R, Fibbe WE. Mesenchymal stem cells inhibit generation and function of both CD34+-derived and monocyte-derived dendritic cells. J Immunol. 2006; 177: 2080-7.

130. Spaggiari GM, Abdelrazik H, Becchetti F, Moretta L. MSCs inhibit monocyte-derived DC maturation and function by selectively interfering with the generation of immature DCs: central role of MSC-derived prostaglandin E2. Blood. 2009; 113: 6576-83.

131. Cutler AJ, Limbani V, Girdlestone J, Navarrete CV. Umbilical cordderived mesenchymal stromal cells modulate monocyte function to suppress T cell proliferation. J Immunol. 2010; 185: 6617-23.

132. Kim J, Hematti P. Mesenchymal stem cell-educated macrophages: a novel type of alternatively activated macrophages. Exp Hematol. 2009; 37: 1445-3.

133. Mosser DM, Edwards JP. Exploring the full spectrum of macrophage activation. Nat Rev Immunol. 2008; 8: 958-69.

134. Choi H, Lee RH, Bazhanov N, Oh JY, Prockop DJ. Anti-inflammatory protein TSG- 6 secreted by activated MSCs attenuates zymosaninduced mouse peritonitis by decreasing TLR2/NF-kB signaling in resident macrophages. Blood. 2011; 118: 330-8.

135. English K, Ryan JM, Tobin L, Murphy MJ, Barry FP, Mahon BP. Cell contact, prostaglandin $\mathrm{E}(2)$ and transforming growth factor beta 1 play non-redundant roles in human mesenchymal stem cell induction of CD4+CD25(High) forkhead box P3+ regulatory $\mathrm{T}$ cells. Clin Exp Immunol. 2009; 156: 149-60.

136. Ge W, Jiang J, Arp J, Liu W, Garcia B, Wang H. Regulatory T-cell generation and kidney allograft tolerance induced by mesenchymal stem cells associated with indoleamine 2,3-dioxygenase expression. Transplantation. 2010; 90: 1312-20.

137. Kavanagh H, Mahon BP. Allogeneic mesenchymal stem cells prevent allergic airway inflammation by inducing murine regulatory $\mathrm{T}$ cells. Allergy. 2011; 66: 523-31.

138. Nemeth K, Keane-Myers A, Brown JM, Metcalfe DD, Gorham JD, Bundoc VG, et al. Bone marrow stromal cells use TGF-beta to suppress allergic responses in a mouse model of ragweed-induced asthma. Proc Natl Acad Sci USA. 2010; 107: 5652-7.

139. Nemeth K, Leelahavanichkul A, Yuen PS, Mayer B, Parmelee A, Doi $\mathrm{K}$, et al. Bone marrow stromal cells attenuate sepsis via prostaglandin $\mathrm{E}$ (2)-dependent reprogramming of host macrophages to increase their interleukin-10 production. Nat Med. 2009; 15: 429 .

140. Akiyama K, Chen C, Wang D, Xu X, Qu C, Yamaza T, et al. Mesenchymal-stem-cell-induced immunoregulation involves FASligand-/FAS-mediated T cell apoptosis. Cell Stem Cell. 2012; 10: 544-55.

141. Li YP, Paczesny S, Lauret E, Poirault S, Bordigoni P, Mekhloufi $\mathrm{F}$, et al. Human mesenchymal stem cells license adult CD34+ hemopoietic progenitor cells to differentiate into regulatory dendritic cells through activation of the Notch pathway. J Immunol. 2008; 180: 1598-608.

142. Zhang B, Liu R, Shi D, Liu X, Chen Y, Dou X, et al. Mesenchymal stem cells induce mature dendritic cells into a novel Jagged-2dependent regulatory dendritic cell population. Blood. 2009; 113: 46-57.
143. Ehninger A, Trumpp A. The bone marrow stem cell niche grows up: mesenchymal stem cells and macrophages move in. J Exp Med. 2011; 208: 421-8.

144. Griffin MD, Elliman SJ, Cahill E, English K, Cereig R, Ritter T. Concise review: adult mesenchymal stromal cell therapy for inflammatory diseases: how well are we joining the dots? Stem Cells. 2013; 31: 2033-41.

145. Gazdic M, Volarevic V, Arsenijevic N, Stojkovic M. Mesenchymal stem cells: a friend or foe in immune-mediated diseases. Stem Cell Rev. 2015; 11: 280-7.

146. Dazzi F, Krampera M. Mesenchymal stem cells and autoimmune diseases. Best Pract Res Clin Haematol. 2011; 24: 49-57.

147. Li W, Ren G, Huang Y, Su J, Han Y, Li J, et al. Mesenchymal stem cells: a double-edged sword in regulating immune responses. Cell Death Differ. 2012; 19: 1505-13.

148. Bernardo ME, Fibbe WE. Mesenchymal stromal cells: sensors and switchers of inflammation. Cell Stem Cell. 2013; 13: 392-402.

149. Ren G, Zhang L, Zhao X, Xu G, Zhang Y, Roberts AI, et al. Mesenchymal stem cell-mediated immunosuppression occurs via concerted action of chemokines and nitric oxide. Cell Stem Cell. 2008; 2 : 141-50.

150. Waterman RS, Tomchuck SL, Henkle SL, Betancourt AM. A new mesenchymal stem cell (MSC) paradigm: polarization into a proinflammatory MSC1 or an Immunosuppressive MSC2 phenotype. PLoS One. 2010; 5:e10088.

151. Monsel A, Zhu YG, Gennai S, Hao Q, Liu J, Lee JW. Cell-based therapy for acute organ injury: preclinical evidence and ongoing clinical trials using mesenchymal stem cells. Anesthesiology. 2014; 121: 1099-121.

152. Muraille E, Leo O, Moser M. Th1/Th2 paradigm extended: macrophage polarization as an unappreciated pathogen-driven escape mechanism? Front Immunol. 2014; 5: 603.

153. Mantovani A, Biswas SK, Galdiero MR, Sica A, Locati M. Macrophage plasticity and polarization in tissue repair and remodelling. J Pathol. 2013; 229: 176-85.

154. Stein M, Keshav S, Harris N, Gordon S. Interleukin 4 potently enhances murine macrophage mannose receptor activity: a marker of alternative immunologic macrophage activation. J Exp Med. 1992; 176: 287-92.

155. Biswas SK, Mantovani A. Macrophage plasticity and interaction with lymphocyte subsets: cancer as a paradigm. Nat Immunol. 2010; 11: 889-96.

156. Peled M, Fisher EA. Dynamic aspects of macrophage polarization during atherosclerosis progression and regression. Front Immunol. 2014; 5: 579

157. Parsa R, Andresen P, Gillett A, Mia S, Zhang XM, Mayans S, et al. Adoptive transfer of immunomodulatory M2 macrophages prevents type 1 diabetes in NOD mice. Diabetes. 2012; 61: 2881-92.

158. Murray PJ, Allen JE, Biswas SK, Fisher EA, Gilroy DW, Goerdt S, et al. Macrophage activation and polarization: nomenclature and experimental guidelines. Immunity. 2014; 41: 14-20.

159. Tiemessen MM, Jagger AL, Evans HG, van Herwijnen MJ, John $\mathrm{S}$, Taams LS. CD4+CD25+Foxp3+ regulatory $\mathrm{T}$ cells induce alternative activation of human monocytes/macrophages. Proc Natl Acad Sci USA. 2007; 104: 19446-51.

160. Raes G, Beschin A, Ghassabeh GH, De Baetselier P. Alternatively activated macrophages in protozoan infections. Curr Opin Immunol. 2007; 19: 454-9.

161. Martinez FO, Sica A, Mantovani A, Locati M. Macrophage activation and polarization. Front Biosci. 2008; 13: 453-61. 
162. Shaul ME, Bennett G, Strissel KJ, Greenberg AS, Obin M. Dynamic, M2-like remodeling phenotypes of $\mathrm{CD} 11 \mathrm{c}+$ adipose tissue macrophages during high-fat diet -- induced obesity in mice. Diabetes. 2010; 59: 1171-81.

163. Melief SM, Schrama E, Brugman MH, Tiemessen MM, Hoogduijn MJ, Fibbe WE, et al. Multipotent stromal cells induce human regulatory $\mathrm{T}$ cells through a novel pathway involving skewing of monocytes toward anti-nflammatory macrophages. Stem Cells. 2013; 31: 1980-91.

164. Melief SM, Geutskens SB, Fibbe WE, Roelofs H. Multipotent stromal cells skew monocytes towards an anti-inflammatory interleukin-10-producing phenotype by production of interleukin-6. Haematologica. 2013; 98: 888-95.

165. Francois M, Romieu-Mourez R, Li M, Galipeau J. Human MSC suppression correlates with cytokine induction of indoleamine 2,3-dioxygenase and bystander M2 macrophage differentiation. Mol Ther. 2012; 20: 187-95.

166. Le Blanc K, Mougiakakos D. Multipotent mesenchymal stromal cells and the innate immune system. Nat Rev Immunol. 2012; 12: 38396.

167. Zheng G, Ge M, Qiu G, Shu Q, Xu J. Mesenchymal stromal cells affect disease outcomes via macrophage polarization. Stem Cells Int. 2015; 2015: 989473.

168. Isakson $\mathrm{M}$, de Blacam $\mathrm{C}$, Whelan $\mathrm{D}$, McArdle $\mathrm{A}$, Clover JP. Mesenchymal stem cells and cutaneous wound healing: current evidence and future potential. Stem Cells Int. 2015; 2015: 831095.

169. Jeffcoate WJ, Harding KG. Diabetic foot ulcers. Lancet. 2003; 361: 1545-51.

170. Jude EB, Blakytny R, Bulmer J, Boulton AJ, Ferguson MW. Transforming growth factor-beta 1, 2, 3 and receptor type I and II in diabetic foot ulcers. Diabet Med. 2002; 19: 440-7.

171. Martin A, Komada MR, Sane DC. Abnormal angiogenesis in diabetes mellitus. Med Res Rev. 2003; 23: 117-45.

172. Fahey TJ 3rd, Sadaty A, Jones WG 2nd, Barber A, Smoller B, Shires GT. Diabetes impairs the late inflammatory response to wound healing. J Surg Res. 1991; 50: 308-13.

173. Seitz O, Schürmann C, Hermes N, Müller E, Pfeilschifter J, Frank S, et al. Wound healing in mice with high-fat diet- or ob gene-induced diabetes-obesity syndromes: a comparative study. Exp Diabetes Res. 2010; 2010: 476969.

174. Wetzler C, Kämpfer H, Stallmeyer B, Pfeilschifter J, Frank S. Large and sustained induction of chemokines during impaired wound healing in the genetically diabetic mouse: prolonged persistence of neutrophils and macrophages during the late phase of repair. J Invest Dermatol. 2000; 115: 245-53.

175. Grice EA, Snitkin ES, Yockey LJ, Bermudez DM, Liechty KW, Segre JA. Longitudinal shift in diabetic wound microbiota correlates with prolonged skin defense response. Proc Natl Acad Sci USA. 2010; 107: 14799-804.

176. Badillo AT, Redden RA, Zhang L, Doolin EJ, Liechty KW. Treatment of diabetic wounds with fetal murine mesenchymal stromal cells enhances wound closure. Cell Tissue Res. 2007; 329: 301-11.

177. Falanga V, Iwamoto S, Chartier M, Yufit T, Butmarc J, Kouttab N, et al. Autologous bone marrow-derived cultured mesenchymal stem cells delivered in a fibrin spray accelerate healing in murine and human cutaneous wounds. Tissue Eng. 2007; 13: 1299-312.

178. Li HH, Fu X. Mechanisms of action of mesenchymal stem cells in cutaneous wound repair and regeneration. Cell Tissue Res. 2012; 348: 371-7.

179. Galindo LT, Filippo TR, Semedo P, Ariza CB, Moreira CM, Camara NO, et al. Mesenchymal stem cell therapy modulates the inflammatory response in experimental traumatic brain injury. Neurol Res Int. 2011; 2011: 564089.
180. Yoon BS, Moon JH, Jun EK, Kim J, Maeng I, Kim JS, et al. Secretory profiles and wound healing effects of human amniotic fluid-derived mesenchymal stem cells. Stem Cells Dev. 2010; 19: 887-902.

181. Mansilla E, Marin GH, Sturla F, Drago HE, Gil MA, Salas E, et al. Human mesenchymal stem cells are tolerized by mice and improve skin and spinal cord injuries. Transplant Proc. 2005; 37: 292-4.

182. Yi R, O'Carroll D, Pasolli HA, Zhang Z, Dietrich FS, Tarakhovsky $\mathrm{A}$, et al. Morphogenesis in skin is governed by discrete sets of differentially expressed microRNAs. Nat Genet. 2006; 38: 356-62.

183. Yi R, Poy MN, Stoffel M, Fuchs E. A skin microRNA promotes differentiation by repressing 'stemness'. Nature. 2008; 452: 225-9.

184. Sonkoly E, Wei T, Janson PC, Saaf A, Lundeberg L, Tengvall-Linder $\mathrm{M}$, et al. MicroRNAs: novel regulators involved in the pathogenesis of psoriasis? PLoS ONE. 2007; 2: e610.

185. Sheedy FJ, O’Neill LA. Adding fuel to fire: microRNAs as a new class of mediators of inflammation. Ann Rheum Dis. 2008; 67 (Suppl 3): iii50-5.

186. Taganov KD, Boldin MP, Chang KJ, Baltimore D. NF-kappaBdependent induction of microRNA miR-146, an inhibitor targeted to signaling proteins of innate immune responses. Proc Natl Acad Sci USA. 2006; 103: 12481-6.

187. Bhaumik D, Scott GK, Schokrpur S, Patil CK, Orjalo AV, Rodier F, et al. MicroRNAs miR-146a/b negatively modulate the senescenceassociated inflammatory mediators IL-6 and IL-8. Aging (Albany NY). 2009; 1: 402-11.

188. Xu J, Wu W, Zhang L, Dorset-Martin W, Morris MW, Mitchell ME, et $a l$. The role of microRNA-146a in the pathogenesis of the diabetic wound-healing impairment: correction with mesenchymal stem cell treatment. Diabetes. 2012; 61: 2906-12.

189. Covas DT, Panepucci RA, Fontes AM, Silva WA Jr, Orellana MD, Freitas MC, et al. Multipotent mesenchymal stromal cells obtained from diverse human tissues share functional properties and geneexpression profile with $\mathrm{CD} 146+$ perivascular cells and fibroblasts. Exp Hematol. 2008; 36: 642-54.

190. Tang W, Zeve D, Suh JM, Bosnakovski D, Kyba M, Hammer RE, et al. White fat progenitor cells reside in the adipose vasculature. Science. 2008; 322: 583-6.

191. Cossu G, Bianco P. Mesoangioblasts-vascular progenitors for extravascular mesodermal tissues. Curr Opin Genet Dev. 2003; 13: $537-42$.

192. Tang Z, Wang A, Yuan F, Yan Z, Liu B, Chu JS, et al. Differentiation of multipotent vascular stem cells contributes to vascular diseases. Nat Commun. 2012; 3: 875.

193. Psaltis PJ, Harbuzariu A, Delacroix S, Holroyd EW, Simari RD. Resident vascular progenitor cell -- diverse origins, phenotype, and function. J Cardiovasc Transl Res. 2011; 4: 161-76.

194. Tavian M, Zheng B, Oberlin E, Crisan M, Sun B, Huard J, et al. The vascular wall as a source of stem cells. Ann NY Acad Sci. 2005; 1044: 41-50.

195. Chen CW, Corselli M, Péault B, Huard J. Human blood-vesselderived stem cells for tissue repair and regeneration. J Biomed Biotechnol. 2012; 2012: 597439.

196. Par TS, Gavina M, Chen CW, Sun B, Teng PN, Huard J, et al. Placental perivascular cells for human muscle regeneration. Stem Cells Dev. 2011; 20: 451-63.

197. Corselli M, Chen CW, Sun B, Yap S, Rubin JP, Péault B. The tunica adventitia of human arteries and veins as a source of mesenchymal stem cells. Stem Cells Dev. 2012; 21: 1299-308.

198. Campagnolo P, Cesselli D, Al Haj Zen A, Beltrami AP, Kränkel N, Katare R, et al. Human adult vena saphena contains perivascular progenitor cells endowed with clonogenic and proangiogenic potential. Circulation. 2010; 121: 1735-45. 
199. Chen WCW, Peault B, Huard J. Regenerative translation of human blood-vessel-derived MSC precursors. Stem Cell Int. 2015; 2015: 375187.

200. Rucker HK, Wynder HJ, Thomas WE. Cellular mechanisms of CNS pericytes. Brain Res Bull. 2000; 51: 363-9.

201. Hellstrom M, Gerhardt H, Kalen M, Li X, Eriksson U, Wolburg H, et al. Lack of pericytes leads to endothelial hyperplasia and abnormal vascular morphogenesis. J Cell Biol. 2001; 152: 543-53.

202. Von Tell D, Armulik A, Betsholtz C. Pericytes and vascular stability. Exp Cell Res. 2006; 312: 623-9.

203. Armulik A, Abramsson A, Betsholtz C. Endothelial/pericyte interactions. Circ Res. 2005; 97: 512-23.

204. Orekhov AN, Bobryshev YV, Chistiakov DA. The complexity of cell composition of the intima of large arteries: focus on pericyte-like cells. Cardiovasc Res. 2014; 103: 438-51.

205. Gaengel K, Genove Ǵ, Armulik A, Betsholtz C. Endothelial-mural cell signaling in vascular development and angiogenesis. Arterioscler Thromb Vasc Biol. 2009; 29: 630-8.

206. Armulik A, Genove Ǵ, Mäe M, Nisancioglu MH, Wallgard E, Niaudet C, et al. Pericytes regulate the blood-brain barrier. Nature. 2010; 468: 557-61.

207. Peppiatt-Wildman CM. The evolving role of renal pericytes. Curr Opin Nephrol Hypertens. 2013; 22: 10-6.

208. Dulmovits BM, Herman IM. Microvascular remodeling and wound healing: a role for pericytes. Int J Biochem Cell Biol. 2012; 44: 1800-12.

209. Dellavalle A, Sampaolesi M, Tonlorenzi R, Tagliafico E, Sacchetti B, Perani L, et al. Pericytes of human skeletal muscle are myogenic precursors distinct from satellite cells. Nat Cell Biol. 2007; 9: 25567.

210. Dellavalle A, Maroli G, Covarello D, Azzoni E, Innocenzi A, Perani $\mathrm{L}$, et al. Pericytes resident in postnatal skeletal muscle differentiate into muscle fibres and generate satellite cells. Nat Commun. 2011; 2: 499 .

211. Dore-Duffy P, Cleary K. Morphology and properties of pericytes. Methods Mol Biol. 2011; 686: 49-68.

212. Armulik A, Genove G, Betsholtz C. Pericytes: developmental, physiological, and pathological perspectives, problems, and promises. Dev Cell. 2011; 21: 193-215.

213. Ding Y, Song N, Luo Y. Role of bone marrow-derived cells in angiogenesis: focus on macrophages and pericytes. Cancer Microenviron. 2012; 5: 225-36.

214. Montiel Eulefi E, Nery AA, Rodrigues LC, Sanchez R, Romero F, Ulrich H. Neural differentiation of rat aorta pericyte cells. Cytometry A. 2012; 81: 65-71.

215. Lin CS, Lue TF. Defining vascular stem cells. Stem Cells Dev. 2013; 22: 1018-26

216. Maximov AA. The lymphocyte as a stem cell common to different blood elements in embryonic development and during the post-fetal life of mammals. Folia Haematologica. 1909; 8: 125-34.

217. Kalinina NI, Sysoeva Y, Rubina KA, Parfenova YV, Tkachuk VA. Mesenchymal stem cells in tissue growth and repair. Acta Naturae. 2011; 3: 30-7.

218. Tolar J, Le Blanc K, Keating A, Blazar BR. Concise review: hitting the right spot with mesenchymal stromal cells. Stem cells. 2010; 28: 1446-55.

219. Iso Y, Spees JL, Serrano C, Bakondi B, Pochampally R, Song YH, et al. Multipotent human stromal cells improve cardiac function after myocardial infarction in mice without long-term engraftment. BiochemBiophys Res Commun. 2007; 354: 700-6.

220. Estrada R, Li N, Sarojini H, An J, Lee MJ, Wang E. Secretome from mesenchymal stem cells induces angiogenesis via Cyr61. J Cell Physiol. 2009; 219: 563-71.
221. Kinnaird T, Stabile E, Burnett MS, Lee CW, Barr S, Fuchs S, et al. Marrow-derived stromal cells express genes encoding a broad spectrum of arteriogenic cytokines and promote in vitro and in vivo arteriogenesis through paracrine mechanisms. Circ Res. 2004; 94 678-85.

222. Liu XH, Bai CG, Xu ZY, Huang SD, Yuan Y, Gong DJ, et al. Therapeutic potential of angiogenin modified mesenchymal stem cells: angiogenin improves mesenchymal stem cells survival under hypoxia and enhances vasculogenesis in myocardial infarction. Microvasc Res. 2008; 76: 23-30.

223. Tang YL, Zhao Q, Qin X, Shen L, Cheng L, Ge J, et al. Paracrine action enhances the effects of autologous mesenchymal stem cell transplantation on vascular regeneration in rat model of myocardial infarction. Ann Thorac Surg. 2005; 80: 229-37.

224. Psaltis PJ, Paton S, See F, Arthur A, Martin S, Itescu S, et al. Enrichment for STRO-1 expression enhances the cardiovascular paracrine activity of human bone marrow-derived mesenchymal cell populations. J Cell Physiol. 2010; 223: 530-40.

225. Haider HK, Jiang S, Idris NM, Ashraf M. IGF-1-overexpressing mesenchymal stem cells accelerate bone marrow stem cell mobilization via paracrine activation of SDF-1alpha/CXCR4 signaling to promote myocardial repair. Circ Res. 2008; 103: 13008.

226. Tang J, Wang J, Guo L, Kong X, Yang J, Zheng F, et al. Mesenchymal stem cells modified with stromal cell-derived factor 1 alpha improve cardiac remodeling via paracrine activation of hepatocyte growth factor in a rat model of myocardial infarction. Mol Cells. 2010; 29: 9-19.

227. Shabbir A, Zisa D, Suzuki G, Lee T. Heart failure therapy mediated by the trophic activities of bone marrow mesenchymal stem cells: a noninvasive therapeutic regimen. Am J Physiol Heart Circ Physiol. 2009; 296: H1888-97.

228. Alfaro MP, Vincent A, Saraswati S, Thorne CA, Hong CC, Lee E, et al. SFRP2 suppression of bone morphogenic protein (BMP) and Wnt signaling mediates mesenchymal stem cell (MSC) self-renewal promoting engraftment and myocardial repair. J Biol Chem. 2010; 285: 35645-53.

229. He W, Zhang L, Ni A, Zhang Z, Mirotsou M, Mao L, et al. Exogenously administered secreted frizzled related protein 2 (Sfrp2) reduces fibrosis and improves cardiac function in a rat model of myocardial infarction. Proc Natl Acad Sci USA. 2010; 107: 21110-5.

230. Brade T, Manner J, Kuhl M. The role of Wnt signalling in cardiac development and tissue remodelling in the mature heart. Cardiovasc Res. 2006; 72: 198-209.

231. Huang JGJ, Mirotsou M, Mu M, Zhang L, Zhang Z. Novel Stem cell paracrine factor protects cardiomyocytes through protein kinase $C$ epsilon selective mechanism. Circulation. 2009; 120: S846.

232. Yagi H, Soto-Gutierrez A, Navarro-Alvarez N, Nahmias $Y$, Goldwasser Y, Kitagawa Y, et al. Reactive bone marrow stromal cells attenuate systemic inflammation via sTNFR1. Mol Ther. 2010; 18: $1857-64$

233. Lee RH, Pulin AA, Seo MJ, Kota DJ, Ylostalo J, Larson BL, et al. Intravenous hMSCs improve myocardial infarction in mice because cells embolized in lung are activated to secrete the antiinflammatory protein TSG-6. Cell Stem Cell. 2009; 5: 54-63.

234. Lopatina T, Kalinina N, Karagyaur M, Stambolsky D, Rubina $\mathrm{K}$, Revischin A, et al. Adipose-derived stem cells stimulate regeneration of peripheral nerves: BDNF secreted by these cells promotes nerve healing and axon growth de novo. PLoS One. 2011; 6: e17899.

235. Rubina K, Kalinina N, Efimenko A, Lopatina T, Melikhova V, Tsokolaeva Z, et al. Adipose stromal cells stimulate angiogenesis via promoting progenitor cell differentiation, secretion of angiogenic 
factors, and enhancing vessel maturation. Tissue Eng Part A. 2009; 15: 2039-50.

236. Gallina C, Turinetto V, Giachino C. A new paradigm in cardiac regeneration: the mesenchymal stem cell secretome. Stem Cells Int. 2015; 2015: 765846.

237. Majka M, Janowska-Wieczorek A, Ratajczak J, Ehrenman K, Pietrzkowski Z, Kowalska MA, et al. Numerous growth factors, cytokines, and chemokines are secreted by human CD34(+) cells, myeloblasts, erythroblasts, and megakaryoblasts and regulate normal hematopoiesis in an autocrine/paracrine manner. Blood. 2001; 97: 3075-85.

238. Rustom A, Saffrich R, Markovic I, Walther P, Gerdes HH. Nanotubular highways for intercellular organelle transport. Science. 2004; 303: 1007-10

239. Sherer NM, Mothes W. Cytonemes and tunnelling nanotubules in cell-cell communication and viral pathogenesis. Trends Cell Biol. 2008; 18: 414-20.

240. Ratajczak J, Wysoczynski M, Hayek F, Janowska-Wieczorek A, Ratajczak MZ. Membrane-derived microvesicles: important and underappreciated mediators of cell-to-cell communication. Leukemia. 2006; 20: 1487-95.

241. Janowska-Wieczorek A, Majka M, Kijowski J, Baj-Krzyworzeka $\mathrm{M}$, Reca R, Turner AR, et al. Platelet-derived microparticles bind to hematopoietic progenitor cells and enhance their engraftment. Blood. 2001; 98: 3143-9.

242. Morel O, Toti F, Hugel B, Freyssinet JM. Cellular microparticles: a disseminated storage pool of bioactive vascular effectors. Curr Opin Hematol. 2004; 11: 156-64.

243. Losche W, Scholz T, Temmler U, Oberle V, Claus RA. Plateletderived microvesicles transfer tissue factor to monocytes but not to neutrophils. Platelets. 2004; 15: 109-15.

244. Lai RC, Chen TS, Lim SK. Mesenchymal stem cell exosome: a novel stem cell-based therapy for cardiovascular disease. Regen Med. 2011; 6: 481-92.

245. Camussi G, Deregibus MC, Bruno S, Cantaluppi V, Biancone L. Exosomes/microvesicles as a mechanism of cell-to-cell communication. Kidney Int. 2010; 78: 838-48.

246. Hariri RJ. The Walker Library of Human Imagination: TEDMED Leadership Conversation [Internet]. Imagining tomorrow's health \& medicine [accessed July 2014]. Available at: http://www.youtube. com/watch? v=M4s1zV0TjlM.

247. Zimmerlin L, Park TS, Zambidis ET, Donnenberg VS, Donnenberg AD. Mesenchymal stem cell secretome and regenerative therapy after cancer. Biochimie. 2013; 95: 2235-45.

248. Caplan AI. Adult mesenchymal stem cells: when, where, and how. Stem Cells Int. 2015; 2015: 628767. 